\title{
Kur’an’a Göre Ötekiler
}

\section{The Others According to the Qur'an}

\author{
Abdulkerim Bingöl a,* \\ ${ }^{a}$ Dr., Muş Alparslan Üniversitesi, Rektörlük, Sağlık Kültür ve Spor Daire Başkanlığı, 49250, Muş/Türkiye. \\ ORCID: 0000-0002-2476-2742
}

\section{MAKALE BILGİSİ}

\section{Makale Geçmişi:}

Başvuru tarihi: 12 Aralık 2017

Düzeltme tarihi: 25 Ocak 2018

Kabul tarihi: 01 Şubat 2018

\section{Anahtar Kelimeler:}

Kur'an

Toplum

Farklı Kimlikler

Ötekileştirme

Ötekilerin Hukuku

\section{ARTICLE INFO}

\section{Article history:}

Received 12 December 2017

Received in revised form 25 January 2018

Accepted 01 February 2018

\section{Keywords:}

Qur'an

Society

Distinct Identities

Othering

Rights of the Others
ÖZ

Akıl ve iradeye sahip olmakla diğer varlıklardan üstün olan insan, basmakalıp bir yapıda olmayıp renk, dil, cins vs. bakımından çeşitlilik arz etmektedir. Medeni bir varlık olarak bir arada yaşamak zorunda olan ve çoğu zaman ortak yaşamı tercih eden insanoğlu, kimi durumda farklılıkları çatışma nedeni ve sorun alanı olarak telakki etmiştir. Hemen her sistemin; inanç, ahlaki kriter, dünya görüşü ve yaşam biçimine göre makbul sayıp merkeze yerleştirdiği veya öteki görüp dışladığı kesimler olmuştur. Farklılıkları zenginlik addederek kimseyi ötekileştirmemek ve farklı olana hakkını teslim etmek nazari olarak mümkün olsa da amelî olarak bunun yaygın olduğu söylenemez. İnançlı ve ahlaklı bireylerden oluşan toplumsal bir yapı inşa etme amacında olan Kur'an, bu bağlamda ekseriyetle inananları muhatap alsa da farklı inanç gruplarını kapsayacak şekilde bir umumi hukuk belirlemiş; ilkesel olarak insanların eşit olduğunu ve farklı kesimlerin bir arada yaşamasının kodlarını ortaya koymuştur. Bununla beraber Kur'an, belli bazı itikadi ve ahlaki kriterler ölçeğinde toplumsal kategorizasyon yapmıştır. Bu çalışmada Kur'an'ın nasıl bir kategorizasyon yaptığı ve tarih boyunca potansiyel olarak öteki muamelesi yapılan farklı dinî, etnik, cinsel ve sınıfsal gruplara nasıl yaklaştığı irdelenmiştir.

\section{A B S T R A C T}

A human who is superior to other beings by possessing reason and willpower, is not a stereotypical structure, but has diversity in terms of color, language, gender and etc. Man, who has to live together as a civilized entity and often prefers common life, has sometimes considered diversity as the cause of conflict and the problem area. In almost every system, there are appreciated and centralized segments or segments that have been marginalized and viewed as the other in regard to their belief, moral criterion, worldview, and way of life. It cannot be said that it is practically widespread, although it is theoretically possible to make no difference and to surrender the right to the different by regarding the differences as wealth. The Qur'an, which aims to build a social structure composed of faithful and moral individuals, has set a common law in this context to cover different belief groups, although it usually deals with believers; in principle, the Qur'an states that people are equal and that different segments could live together. Nevertheless, the Qur'an has categorized the society in a certain scale of ideological and moral criteria. This study explores how the Qur'an categorizes and approaches the various religious, ethnic, sexual and class groups that have been potentially subjected to the treatments of 'the other' throughout history.

\section{Giriş}

Gücü ve iradesi mutlak olduğu halde Allah (c.c.), kâinattaki varlıkları hikmet dairesinde birbirine bağlamıştır. İnsan iradesine bağlı olan kesbi hakikatler arasında nedensellik ilişkisi kuran Allah, aynı şekilde kâinattaki kevni hakikatleri de birbiriyle ilişkilendirmiştir (Bingöl, 2015: 334). Sebepsonuç ilişkisi üzerine kurulan ve Ayetullah/Sünnetullah olarak isimlendirilen varlık âlemindeki sistemde (Ra'd, 13/8; İsrâ, 17/77; Fetih, 48/23; Mülk, 67/3), kevni varlıklar tek bir şekilde yaratılmayıp bir denge dâhilinde çeşitli ve birbirinden farklı yaratılmıştır. Aynı şekilde kâinatın tek sorumlu varlığı olan insan (Ahzâb, 33/72) da tek bir formda değil birbirinden ayrı özelliklerde yaratılmış veya bazı etkenlerle farklılaşmıştır. Yeryüzü; iklim, verim, doğal koşullar vs. konularda insana sağladığı imkân ve avantaj

\footnotetext{
* Sorumlu yazar/Corresponding author.

e-posta: akerimbingol@hotmail.com
} 
hususunda mütenevvi olduğu gibi yerkabuğu üzerinde yaşayan insan başta olmak üzere canlıların imkânlardan istifade edebilme kapasiteleri de birbirinden farklıdır. Allah, ilahi hikmetin gereği ekosistemi bilemediğimiz kadar çeşitli yarattığı gibi akıl, vücut, güç, yetenek, sermaye, imkânları değerlendirme kapasitesi vs. açısından bazı insanları bazılarından farklı yaratmıştır. Bu durum insanlar arasında işbölümü yapılması, içtimai hayatın tesisi, beşerî ilişkilerin sistem dâhilinde birbirine muhtaç ve birbirini tamamlayan bir yapı olması açısından önemlidir. Dünya hayatında onların geçimliklerini aralarında biz paylaştırdık. Birbirlerine iş gördürmeleri için, (çeşitli alanlarda) kimini kimine, derece derece üstün klldık (Zuhruf, 43/32). Kur'an, Allah tarafindan yapılan bu paylaşımın imtiyaz ve üstünlük sebebi olarak görülmemesini emretmekte ve bunun ders alınması gereken bir mesele olduğunu vurgulamaktadır. $O$, sizi yeryüzünde halifeler (oraya hâkim kimseler) yapan, size verdiği nimetler konusunda sizi sınamak için bazınızı bazınıza derece derece üstün kılandır (Enam, 6/165). Allah katında en değerli olanınız, O'na karşı gelmekten en çok sakınanınızdır (Hucurat, 49/13).

İnsanlık tarihi boyunca kâinattaki doğal ya da sonradan oluşan farklılıklar; kavga, çatışma, cepheleşme ve ötekileştirme sebebi olarak insanlığın meşum mirası olagelmiştir. Toplumu kategorilere ayıran; bazı cinsel, sınıfsal ve sosyal kesimleri ötekileştiren anlayış tarihin birçok döneminde toplumu bir arada tutan ilişkileri zehirlemiştir. Hz. Adem'in çocuklarından Kabil'in Habil'e uyguladığı şiddet ile başlayan ve farklı zaman ve zeminlerde çeşitli boyutlarda tezahür eden ötekileştirme (Gündüz, 2012: 483); değişik toplumsal kesimlerde ortaya çıktığı gibi dinî gruplar arasında da görülen bir olgudur. Ayrı dinlere mensup olanların birbirlerini "öteki” olarak saydığı gibi aynı dinin temel kaynaklarını kullanan her bir firka; sosyolojik, politik, ekonomik ve etnik farklılıklardan dolayı kendi dışındakilerini “öteki” olarak görebilir. $\mathrm{Bu}$ anlayışı Müslümanlar dâhil her dinî toplulukta görmek mümkündür (Albayrak, 2005: 7). Ötekileştirme anlayışı nedeniyle farklılıkları koruyarak bir arada yaşamak problem olagelmiştir (Aydın, 2009: 9-10).

Oysa çağlar boyu olduğu gibi günümüz dünyasında küreselleşmenin de etkisiyle çoğulculuğu muhafaza ederek bir arada yaşamak kaçınılmaz bir hal almıştır. Zira toplumlar arasında doğanın koyduğu engellerin, ulaşım ve iletişim imkânlarının gelişmesiyle artık ortadan kalktığ görülmektedir. Zaman, farklı unsurların çeşitliliğini koruyarak ortak yaşamı inşa etmeye zorluyor. Fakat birbirinden farklı olan sosyal ve siyasal unsurlar arasında maddi engellerin kalkmasına rağmen zihnî engeller hala varlığını sürdürmektedir. Küreselleşme, insanları etkilese de halkların büyük ölçüde yerel kaldığı; kendi mahalli değerlerine aşırı derecede bağlı olduğu görülmektedir. Bu nedenle toplumda aidiyet duygusu, dinî ve etnik kimlikler global değer yargılarına nazaran oldukça etkili bir konumdadır (Y1ldırım, 2012: 170). Bu kimliklerin etkili olması tek başına problem değildir. Fakat bu durum diğer kimlikleri ötekileștirmeyi beraberinde getirince problem oluvermektedir.

Yapılan araştırmalar, önyargının ve bunun sonucu olarak ortaya çıkan ötekileştirme anlayışının fitrî olmayıp öğrenilen bir davranış olduğunu göstermektedir (Tekeli, 2011: 3). Dolayısıyla bundan kurtulmak da mümkündür. Günümüzde büyük savaşlara ve sonu gelmez çelişki ve çatışmaya sebep olan ötekileştirme anlayışının aşılması durumunda geçmişteki kimi kavimlerden bize miras kalan ve çağımızın derin sorunlarından olan tek inanca, tek kültüre, tek etnik yapıya, tek cinse, tek sınıfa dayalı ve doğa karşıtı düşünceden kurtulmak kolaylaşacaktır. Zira teklik anlayışı aynı anda ötekileştirmeyi meydana getirmektedir. Öte yandan Kur'an penceresinden olaylara bakan ve buna göre davranışlarını şekillendirmek isteyen Müslüman bireyin bu konu hakkında Kur'an'ın yaklaşımını öğrenmesi oldukça mühimdir. Kur'an'ın evrenselliğini ortaya koymak, ona duygularımızı karıştırmadan yorumlamak (Elmalı, 1999: 47), güncel problemlere Kur'an'ın bakışını irdelemek ve spesifik olarak Kur'an'ın ötekiye yaklaşımını ortaya koymak önemli görüldüğünden bu çalışma yapılmıştır.

Sözlükte "bilinenden ayrı, diğer ve daha uzakta olan șey" (Akalın vd., 2005: 1551; Püsküllüoğlu, 2010: 755) şeklinde tanımlanan öteki, felsefede "belli bir konum veya varlığın karşıtı olan, onun tam karşı kutbunda bulunan varlık" (Cevizci, 2005: 1296) şeklinde tanımlanmıştır. Bir anlamda bireyin dışında kalan yakın ve uzak herkes "öteki” olarak addedilir. Bizden olmayan ve bize uymayan "öteki” aynı anda değersizdir, güvensizdir ve yok edilmeyi hak etmiş düşmandır (Durmuşoğlu vd., 2008: 623).

“Öteki”, kişiden kişiye farklılık arz eden bir kavram olduğu gibi toplumdan topluma göre de farklılık arz etmektedir. Mesela milliyetçi birisi için öteki, farklı bir etnik yapıya mensup olanlar için kullanılır. Toplum içinde bir deli akılllı kimseler nazarında öteki addedilebilir (Fentress, 2011: 182). Greklere göre merkezdeki asıl kimlik "Grek" kimliği olup "öteki" ise yabancı olan herkestir (Gündoğdu, 2008: 76). Batının zihin dünyasında "biz" beyaz ırk, Hristiyanlık ve Roma ile Yunan medeniyetinin oluşturduğu kimliktir. "Öteki”" ise bunun dışındaki kimliklerdir (Gökkır, 2005: 44). İslam literatüründe motamot "öteki" anlamında kullanılan bir kavram yoktur. Ancak İlahi-gayri ilahi, hak-batıl, semavibeşeri, kitapl1-kitapsız gibi karşıt kavramların ikincileri bir yönüyle "öteki” sayılabilir (Çalışkan, 2007: 8).

"Öteki” mahiyetine dayalı olarak oluşturulmuş pek çok olumsuz toplumsal akım ve olgu vardır. Irkçılık, soykırım, etnikmerkezcilik, seksizm, tekkültürcülük, yabancı düşmanlığı, İslamofobi, vb. akımlar; ötekiyi aşağılama, dişlama ve onlara kinci yaklaşma şeklinde tezahür eden ve sosyal hayatı etkileyen olgulardır (Aktaş, 2010: 177; Sevinç, 2010: 197; Tekeli, 2011: 2).

Düşman yaratmak veya var olan bir düşman ile kavga etmek hakim güçlerin, hükümranlıklarını tesis edip devam ettirmek için başvurduğu yöntemlerden birisidir. Her gerçek güç kendi gerçek düşmanını saptar (Türk, 2013: 315) ve bir anlamıyla varlığını düşmanının varlığıyla garanti altına alır.

Kendisini merkeze yerleştiren anlayış tarafından öteki görülene yapılan muamele konusunda farklı formlar vardır. Bunlardan en yaygın olanı onları merkezde olan yaşam biçimine sokmaya çalışmak, kendi kimliğini gizlemeye zorlamak (Toprak vd., 2010: 72-77) veya iç düşman ilan edip kendi egemenliğini koruma refleksiyle onu yok etmeye kalkışmaktır. Hatta bunun meşruluğuna inanmak bile söz konusudur (Türk, 2013: 208-209). Bunların dışında ötekiyi bir araç olarak görüp kendi amaçları uğruna kullanılan bir nesne şeklinde değerlendirmek, ötekiyi bir insan olarak gördüğü halde onu insani haklarından mahrum bırakmak 
şeklinde yaklaşımlar vardır. Bunlara göre nispeten daha az problemli bir tavır ise ötekiyi özne olarak görmek ve ona insani değerlerini teslim etmektir (Durmuşoğlu vd., 2008: 624-625).

"Her kötülüğün içinde bir miktar iyilik vardır" söyleminde olduğu gibi bütün olumsuzluğuna rağmen ötekileştirmenin olumlu bir etkisinin olduğu söylenebilir. Buna binaen denebilir ki ötekileştirme her zaman menfi sonuçlar vermez. Psikolojik olarak hepimizin bir şekilde tecrübe ettiği ötekileştirme anlayışı aslında kendilik bilincinin oluşmasında etkilidir (Durmuşoğlu vd., 2008: 623). Ötekinin olmadığı bir toplumu tasavvur etmek zordur. Ötekinin olmadığı bir toplumda kimlikten, toplumsal gruplardan söz edilemez. Ötekileştirme, çatışmaya neden olduğu gibi yaratıcılığın mekanizmalarını oluşturan özenmeye, rekabete, gelişmeye hatta olumlu anlamda işbirliği yapmaya kaynaklık eder (Tekeli, 2011: 2).

\section{Kur’an'ın “Öteki”ye Yaklaşımı}

Kur'an'ın mücadele alanlarından birisi de ötekileştirme anlayışıdır. Nitekim Kur'an; insanı değerli görmekte, fitri ve beşeri farklılıklardan ötürü başkasını ötekileştirip hor görmeyi haram saymakta ve insanların yaratılışta eşit olduğunu ortaya koymaktadır. Andolsun, biz insanoğlunu şerefli kıldık. (İsrâ, 17/70), Ey iman edenler! Bir topluluk bir diğerini alaya almasın. (Hucurât, 49/11), Ey insanlar! Şüphe yok ki, biz sizi bir erkek ve bir dişiden yarattık ve birbirinizi tanımanız için sizi boylara ve kabilelere ayırdık (Hucurât, 49/13). Bu ayetlerde beyan buyurulduğu gibi insan doğuştan kıymetlidir, atası birdir, biri diğerine üstün değildir. Bireyler, toplumlar, kavimler, milletler vs. hepsi eşittir. Hatta Kur'an'ın bu yaklaşımından ötürü ilk dönemlerde toplumsal yapı tarafından ötekileştirilen fakir, engelli, köle kadın vs. İslam dinini kabul etmiş, kendilerini üstün rrk ve yüce din mensubu olarak gören kesimlerin büyük bir kısmı ise Müslüman olmayı reddetmiştir (İbn Hişam, 2009: 237-297; Halebî, 2008: 381; Dehlan, 2001: 175-195).

İnsan; görüntüsü, mizac1, özgür iradesiyle kendi davranışlarını kontrol edebilme kabiliyeti, doğa ve tarih üzerinde belirleyici olabilme özelliğini (Şirbinî, 2004: 358; Mezherî, 2007: 262; Durmuşoğlu vd., 2008: 627) ile hayat, ilim, kudret, irade, duyma, görme, tedbir, hikmet gibi Allah'ın sıfatlarından olan bazı kabiliyetleri haiz olmakla diğer varlıklardan üstün kılınmıştır (Endulusî, 2007: 503504; Kurtubî, 2006: 368; Haddad, 2001: 240). Biz, gerçekten insanı en güzel bir biçimde yarattık (Tîn, 95/4). Andolsun, biz insanoğlunu şerefli kıldık (İsrâ, 17/70). Güzel yaratılan ve şerefli kılınan insanın kendisidir; bütün insanlar bunda müşterektir.

İnsanların yaratılışta eşit olduğunu, köken itibarıyla kimsenin ötekileştirilemeyeceğini ortaya koyan Kur'an, herkese hitap eden perspektifiyle de kimseyi "öteki”" olarak kabul etmez. (Ey Muhammed!) Seni ancak âlemlere rahmet olarak gönderdik (Enbiyâ, 21/107). Bu ayette dikkat çeken iki mesaj vardır. Birincisi Hz. Peygamber'in bütün insanlığa gönderildiğidir. Bundan kimse müstesna değildir. Dolayısıyla öteki yoktur. İkincisi, Hz. Peygamber'in rahmet peygamberi oluşudur. $\mathrm{O}$, müşriklere bile beddua etmekten kaçınmıştır (Mezherî, 2007: 513; Sıddik Hasan Han, 1999: 441-442; İbn Aşur, "tarihsiz": 167-168). Hitapta "öteki" bırakmayan Kur'an'ın değer normlarında ötekileştirme yoktur. Kur'an, tüm insanların yaratılışta ve hukukta eşit olduğuna vurgu yapmakta, farklılıkları iletişim ve tesanüt vasıtası olarak görmektedir (Y1lmaz, 2008: 138).

Kur'an'ın İslami topluluk için ortaya koyduğu üst kimlik olan "ümmet kavramı", tarih boyunca en kapsayııı üst kimliklerinden birisi olagelmiş ve Müslümanların en kapsamlı sosyal birliğinin adı olmuştur. Ümmet, farklı sosyolojik grupların üstünde bir hedefi gerçekleştirmiştir. Bu kavram, ortak amaç etrafında özgür iradeyle bir araya toplanmış insanları ifade etmektedir. Kur'an; Müslümanların üst kimliğini teşkil eden ümmet çatısı altında bütün müntesiplerini birleştirmekte, etnik ve sınıfsal birlik esasına dayalı cemiyet yapısını yıkarak, onun yerine, inanç merkezli bir toplum meydana getirmeyi hedeflemektedir (Durmuş, 2003: 26).

Kur'an, insanı ümmet üst kimliği etrafinda birleştirirken tekleştirmekten ve özgür iradelerini yok saymaktan uzak bir yaklaşım sergilemiştir. Zira Kur'an, insanlar tek tip yaratılmadığına ve farklı dinlere intisap etmiş olmalarına özellikle vurgu yapmıştır (İbnu'l-Cevzî, 2010: 408-409; Şirbinî, 2004: 96; Haddad, 2001: 506). Rabbin dileseydi insanlarl (aynı inanca bağll) tek bir ümmet yapardl. Fakat Rabbinin merhamet ettikleri müstesna, onlar ihtilafa devam edeceklerdir. Zaten onları bunun için yarattı (Hûd, 11/118). Böylece Kur'an, beşeriyetteki farklılığın ilahi bir tasarrufun kapsamında olduğunu ortaya koymuştur.

Ötekileştirmeyi eski bir hastalık olarak nitelendiren Kur'an (Şirbinî, 2004: 81); insanların birbirlerine üstünlük taslamalarını, bir grubun ötekini hor görmesini haram saymaktadır. Ey iman edenler! Bir topluluk bir diğerini alaya almasin. Belki onlar kendilerinden daha iyidirler. Kadınlar da diğer kadınlarl alaya almasın. Belki onlar kendilerinden daha iyidirler. Birbirinizi karalamayın, birbirinizi (kötü) lakaplarla çă̆ırmayın (Hucurat, 49/11).

Kur'an, hatalı kimseyi ötekileştirmeden ona müsamaha göstermeyi ve müşrik dahi olsa insanlara iyi davranmayı emretmiştir (İbnu'l-Cevzî, 2010: 180; Haddad, 2001: 244). Sen af yolunu tut, iyiliği emret, cahillerden yüz çevir (A'râf, 7/199). Böylece Kur'an, bir arada yaşamın düsturunu belirlemiştir.

Kur'an'a göre Müslüman, zulme uğradığında karşı tarafa gücü yetse bile onlara zulmetmez, itidalli davranır, öfke ve intikam duygusuyla değil affedici yaklaşır ve üstelik kötülüğe karşılık iyilik yapar (Taberî, "tarihsiz": 120; İbnu'lCevzî, 2010: 541; Şirbinî, 2004: 237; Mezherî, 2007: 149; Şimşek, 2012: 419). Onlar bollukta ve darlıkta Allah yolunda harcayanlar, öfkelerini yenenler, insanlarl affedenlerdir. Allah iyilik edenleri sever (Âl-i İmrân, 3/134). Oysa ahlaki öğretiler ile terbiye edilmemiş insanlar, haksızlığa uğradıklarında kötülüğe misliyle hatta daha fazlasıysa karşılık vermek isterler. Mekke döneminde Müslümanlar, kendilerine her türlü eziyeti yapan kişilerden intikam almak istediler. Ancak Allah, onları kötülük yapmaktan, intikam duygusuyla hareket etmekten nehyetti ve kötülüğe karşı iyilik yapmayı emretti (Zemahşerî, 2009: 194; Şimşek, 2012: 420). Iyilikle kötülük bir olmaz. Kötülüğü en güzel bir şekilde sav. Bir de bakarsın ki, seninle arasında düşmanlık bulunan kimse sanki sicak bir dost oluvermiştir. Bu güzel davranışa ancak sabredenler kavuşturulur (Fussilet, 41/34-35). Sen şimdi güzel bir şekilde hoşgörü ile muamele et (Hicr, 15/85). 
Yukarıda ifade edildiği gibi merkezdeki "ben"e göre şekillenen "öteki"nin farklılık gösteren bir mahiyeti vardır. Birisine göre öteki olan başka birisine göre öteki olmayabilir. Kur'an'ın bazı kesimlere ötekileştirici bir yaklaşımının olduğu konusunda tartışmalar vardır. Bu kapsamda potansiyel olarak öteki görülenlerden dört kesime Kur'an'ın yaklaşımı değerlendirilecektir.

\subsection{Farklı İnanç Gruplarını Ötekileştirme}

Dini, inancı veya mezhebi farklı olanların birbirleriyle ilişkileri -istisnalar olmakla birlikte- tarih boyunca sorunlu olmuştur. Zenginlik addedilmesi gereken farklılık; genelde ayrımcılık yapmaya ve şiddet uygulamaya sebebiyet vermiş, küresel ölçekte sömürgeleştirme ve kolonyalizme neden olmuştur. Her bir dinî grup veya inançsal akım kendi mensuplarına, ötekiden farklı bir inanış ve anlayış tarzı benimsetmek, onlara algılama hazır kalıpları sunmak amacında olagelmiştir. Bunun sonucu olarak din mensuplarında etnosantrik bir anlayış; kendi inancını doğru ve mükemmel görmek, karşısındakini öteki ve olumsuz algılamak bakış açısı gelişmiştir. Oysa toplumların öteki ile ilişki kurma ve onunla yaşamı paylaşma zorunluluğu vardır (Gündüz, 2012: 483-484; Hökelekli, 2007: 406).

Kur'an, evrensel bir kitap olması münasebetiyle her zamana ve her topluluğa hitap etmektedir. İçerdiği inanç ilkeleri, ahkâm ve ahlaki kriterlerden, hitabının umumi olmasından ve "âlemler", "insanlar" vb. kavramlardan anlaşılacağı üzere Kur'an'ın muhatabı herkestir. Bu manada maada ve öteki yoktur.

Mükellefiyet noktasında insanlar arasında ayrım yapmayan Kur'an, semavi kitaplar ve peygamberler arasında da ayrım yapmaz. Peygamber, Rabbinden kendisine indirilene iman etti, mü'minler de (iman ettiler). Her biri; Allah'a, meleklerine, kitaplarina ve peygamberlerine iman ettiler ve şöyle dediler: "Onun peygamberlerinden hiçbirini (diğerinden) ayırt etmeyiz" (Bakara, 2/285). Kur'an, geçmiş zaman peygamberlerine gönderilen ilkelerin aynısının $\mathrm{Hz}$. Muhammed'e gönderildiğini ifade etmek ve onlardan bazılarının ismini zikretmek suretiyle dinlerin kaynak ve hedef itibarıyla özünde aynı olduğunu bildirmiştir (Zemahşerî, 2009: 209; Şirbinî, 2004: 631-632; Siddik Hasan Han, 1999: 434; İbn Aşur, "tarihsiz": 139-141; Şimşek, 2012: 440). "Dini dosdoğru tutun ve onda ayrılı̆̆a düşmeyin!" diye Nûh'a emrettiğini, sana vahyettiğini, İbrâhim'e, Mûsâ'ya ve İsâ'ya emrettiğini size de din kldd (Şûrâ, 42/13). Şüphesiz bu (İslâm), tek ümmet (din) olarak sizin ümmetiniz (dininiz)dir (Enbiyâ, 21/92). Dinler ve peygamberler arasında ayrım yapmayan Kur'an, toplumsal konularda insanlar arasında da ayrımcılık yapmaz. Allah'a ibadet edin ve ona hiçbir şeyi ortak koşmayın. Ana babaya, akrabaya, yetimlere, yoksullara, yakın komşuya, uzak komşuya, yanınızdaki arkadaşa, yolcuya, elinizin altındakilere iyilik edin. Şüphesiz, Allah kibirlenen ve övünen kimseleri sevmez (Nisâ, 4/36). Bu ayette Müslümanın iki temel özelliğinden; tevhit inancı ve akrabadan başlamak üzere diğer insanlara iyilik etmekten söz edilmiştir (Razî, 2009: 76-79; Şirbinî, 2004: 347-348; Şimşek, 2012: 505506). İnsana iyilik yapmayı emreden yukarıdaki ayette iyilik yapılması gereken kişiler mutlak zikredilmiştir; ilgili kişilerin mümin olma şartı ayette yoktur.
Köken itibarıyla insanları eşit gören, bütün insanlığa hitap eden, semavi kitaplar arasında ayrımcılık yapmayan ve içtimai meselelerde insanlar arasında fark gözetmeyen Kur'an; neticede inanç merkezli bir yap1 inşa etmeyi hedeflediği için dinin temel ilkelerinin tamamını veya bir kısmını yok sayan kesimleri bir yönüyle öteki olarak görmektedir. Bu noktada Kur'an'ın insanları, ilahi düstura olumlu veya olumsuz yaklaşımları üzerinden inançlı veya inançsız olarak nitelediği, bu çerçevede bir kategorizasyon ve inanç merkezli bir ötekileştirme yaptığını söylemek mümkündür.

Bu bağlamda Müslümanın zihin dünyasında ötekinin şekillenmesinde Kur'an'ın etkisi olmuştur. Zira Kur'an'da yer alan "mümin", "müşrik", "kâfïr", "münafik" ve "ehlikitap" gibi kategorisazyon ve örneğin Allah katında tek hakiki dinin İslam oluşu, müşriklerin pislik sayılması, mescidi harama yaklaşmalarının haram olması, kâfirlerin düşman, Yahudilerin nankör, lanetli vs. olması doğal olarak onları ötekileştirir (Hökelekli, 2007: 407). Hatta Kur'an'ın müşrik tarifi ve müşriklerle ilişkiyi düzenleyen ayetlerden yola çıkarak Müslümanların ötekileri yok etmekle mükellef olduğunu İslami topluluğun öteki ile ilişkisinin savaş esasına dayalı olduğunu düşünenler olmuştur. F1khın tedvin edildiği dönemde vuku bulan savaşlarda genellikle Müslümanların galip gelmesi, fetihlerin süreklilik arz etmesi ve İslam idaresinin bundan büyük fayda sağlaması nedeniyle Müslümanların, Müslüman olmayanlara karşı sürekli cihad pozisyonunda olması gerektiği anlayışı daha da kökleşmiştir. Günümüzde ise objektif olarak şartların değişmesi ile birlikte İslam'ın aslında barış dini olduğu ve hiçbir şekilde saldırıyı ve ötekisini yok etmeyi amaçlamadığı inancı revaç bulmaktadır (Yaman, 2008: 100-102).

İslam dininin savaşa yaklaşımından bağımsız olarak ifade edilmeli ki Kur'an, inanç esası üzerinde bir kategorizasyon yapmaktadır. Nitekim Kur'an, inananları Allah'ın taraftarı inanmayanları ise Şeytan'ı taraftarı olarak isimlendirmektedir. Kim Allah'l, onun peygamberini ve inananlart dost edinirse bilsin ki şüphesiz Allah taraftarlarl galiplerin ta kendileridir (Mâide, 5/56). Şeytan onlart hâkimiyeti altına alıp kendilerine Allah'ı anmayı unutturmuştur. Iște onlar șeytanın tarafinda olanlardır. Iyi bilin $k i$, şeytanın tarafinda olanlar ziyana uğrayanların ta kendileridir (Mücâdele, 58/19). Keza Kur'an, Hz. Lut'un kavminin şahsında sapkın kimseleri kötü toplum olarak nitelendirmektedir. Gerçekten onlar kötü bir toplum idiler, fasık (Allah'ın emrinden çıkan kimseler) idiler (Enbiyâ, 21/74). Nihayet Kur'an, inananları ve inanmayanları aynı sure içerisinde peş peşe gelen ayetlerde net bir şekilde ayrıştırmış ve inanmayanları "mahlûkatın en kötüleri, inananları ise en iyileri” olarak zikretmiştir. Şüphesiz, inkâr eden kitap ehli ile Allah'a ortak koşanlar, içinde ebedi kalmak üzere cehennem ateşindedirler. İşte onlar yaratıkların en kötüsüdürler. Süphesiz, iman edip, salih ameller işleyenler var ya; işte onlar yaratıkların en hayırlısıdırlar (Beyyine, 98/6-7).

\subsubsection{Müşrik ile İlişkilerin Sinırlandırılması}

Kur'an, toplumsal düzeni kurarken her şeyden evvel sağlam bir inancı temele yerleştirmekte, toplumu birleştiren esas harcın iman olduğunu ortaya koymakta ve bu dairenin dışında kalanlar ile ilişkileri sınırlandırmaktadır. Mü'minler, mü'minleri bırakıp inkârcıları dost edinmesin (Âl-i İmrân, 
3/28). Ey inananlar! Yahudi ve hiristiyanlarl dost edinmeyin (Mâide, 5/51). Sizin dostunuz ancak Allah'tır, Resûlüdür ve Allah'ın emirlerine boyun eğerek namazı kılan, zekâtı veren mü'minlerdir. Kim Allah'l, onun peygamberini ve inananları dost edinirse bilsin ki şüphesiz Allah taraftarlarl galiplerin ta kendileridir. Ey iman edenler! Sizden önce kendilerine kitap verilenlerden dininizi alaya alıp oyuncak edinenleri ve öteki kâfirleri dost edinmeyin (Mâide, 5/55-57). Mekke'de kalan akrabalarını terk etmek istemeyen Müslümanlar hakkında nazil olan (İbnu'l-Cevzî, 2010: 224; Haddad, 2001: 313) aşağıdaki ayette beyan edildiği gibi en yakın akraba dahi olsalar inkârcilarla dostluk kurulamaz. Ey iman edenler! Eğer küfrü imana tercih ederlerse, babalarınızı ve kardeşlerinizi bile dost edinmeyin. İçinizden kim onları dost edinirse, işte onlar, zalimlerin ta kendileridir (Tevbe, 9/23). Aynı mesele hakkında başka bir ayette Allah, müşrikleri düşman olarak nitelemek suretiyle onlarla dostluk kurmanın ne kadar büyük bir hata olacağına işaret etmektedir (Taberî, "tarihsiz": 68-69; Maturidî, 2005: 103-104; Zemahşerî, 2009: 499; Ateş, 1989: 378-379; Şimşek, 2012: 213-214). Ey Iman edenler! Benim de düşmanım, sizin de düşmanınız olanlarl dost edinmeyin. Siz onlara sevgi gösteriyorsunuz. Hâlbuki onlar size gelen hakkl inkâr ettiler. Rabbiniz olan Allah'a inandınız diye Resûlü ve sizi yurdunuzdan çıkarlyorlar. Ĕger rızamı kazanmak üzere benim yolumda cihad etmek için çıktıysanız (böyle yapmayın). Onlara gizlice sevgi besliyorsunuz. Oysa ben sizin gizlediğinizi de, açı̆̆a vurduğunuzu da bilirim. Sizden kim bunu yaparsa mutlaka doğru yoldan sapmıştır (Mümtehine, 60/1).

Müslümanlar ile müşriklerin ilişkileri hakkında nazil olan ayetlerden anlaşılacağı gibi Kur'an'a göre inkârcılar ötekidir. Zira onlar, Allah katında asla affedilmeyecek (Bakınız, Nisa, 4/48) ve en büyük günah olan şirk (Taftazani, "tarihsiz": 141) cürmünü ittihaz etmiştir. Bundan ötürü onlarla siyasal ve toplumsal ilişkiler tahdit altındadır. $\mathrm{Bu}$ bağlamda müminlerin müşriklerle kamu düzenini tehlikeye atacak şekilde siyasal birlik kurması, sır paylaşımında bulunması, ileri derecede dostluk kurması ve onlara sevgi beslemesi yasaktır. Öyle ki Müslümanlar ile Müslüman olmayanların birbirinden miras alması bile söz konusu olamaz (Buharî, 1980: Kitabu'l-Faraid, 85/26-6864; Kurtubî, 2006: 99; Merağî, 1985: 196; Ateş, 1989: 222). Bu da doğal olarak İslami toplum ile müşrikler arasında ayrışmaya ve Müslümanların egemen olduğu toplumsal yapılarda müşriklerin ötekileştirilmesine neden olmaktadır.

\subsubsection{Müşrik ile Savaş}

Kur'an'da cihad, kital, harb ve türevlerini içeren birçok ayet vardır (Salmazzem vd., 2016: 231). Bu ayetlerin bir kısmı Müslümanların sayıca az olduğu ve hâkimiyetin müşriklerde bulunduğu Mekke döneminde, bir kısmı da Müslümanların hâkimiyet tesis ettiği Medine döneminde inmiştir. Cihad ayetleri olarak isimlendirilebilecek söz konusu ayetlerin içerdiği ahkâm hakkında farklı yorumlar yapılmıştır. Cihad ayetleri ekseninde yapılan bazı yorumlara bakılırsa İslam'da cihad, sadece savunma temellidir. Buna binaen "savaşan ile savaş, savaşmayan ile barış" yapmak ilahi bir emirdir. Ey iman edenler! Hepiniz topluca barış ve güvenliğe (Íslam'a) girin (Bakara, 2/208). Ayetteki "sılm" barış manasındadır (Şirbinî, 2004: 157; Şimşek, 2012: 227). Allah bu ayet ile topyekûn barışa girmeyi emretmiştir. Müslümanlara aktif olarak savaş açmayan kimselere iyilik yapmayı ve onlara adil davranmayı emreden birçok ayet vardır (Zemahşeri, 2009:
504). Allah sizi, din konusunda sizinle savaşmamış, sizi yurtlarınızdan da çıkarmamış kimselere iyilik etmekten, onlara âdil davranmaktan men etmez. Şüphesiz Allah âdil davrananlart sever (Mümtehine, 60/8). Eğer onlar sizden uzak durur, sizinle savaşmayıp size barış teklif ederlerse; Allah, onlara saldırmak için size bir yol (yetki) vermemiştir (Nisâ, 4/90). Yukarıdaki ayetlerden anlaşılacağı gibi müminler açısından savaşın meşru gerekçesi karşı tarafın saldırısıdır. Müslümanlara saldırı gerçekleşmediği sürece savaş meşru olamaz. Dolayısıyla sırf inancı farklı diye kimseye savaş açılamaz. Müslüman olmayan kimseler ile barış yapmak caizdir. Buna göre anlaşmaya yanaşan ve savaştan uzak duran kâfirlerle savaşmak haramdır. Müslümanları dinden döndürme faaliyetleri olursa mürted ile savaşılabilir, aksi takdirde onlara savaş açmak yasaktır.

Kahir ekseriyet ise cihadı savunma ile sınırlandıran ayetlerin hükmümün mensuh olduğunu iddia eder. Buna göre kâfirlere savaş açmanın gerekçesi küfrün kendisidir ve yeryüzündeki insanların tamamı Müslüman oluncaya kadar savaş yapmak Müslümanların üzerinde dini bir vazifedir (Serahsî, 1989: 23 ile 98; Nevevî, 1980: 112-117; Karafî, 1994: 387; Elik, 2006: 120-122). Onlardan herhangi saldırının olup olmaması (Razî, 2009: 178; Şimşek, 2012: 549) durumu değişstirmez. (Ey Muhammed!) Artık Allah yolunda savaş! Sen ancak kendinden sorumlusun! Mü'minleri de savaşa teşvik et (Nisâ, 4/84). Baskı ve şiddet kalmayıncaya ve din tamamen Allah'ın oluncaya kadar onlarla savaşın. Ĕger (küfürden) vazgeçerlerse şüphesiz ki Allah onların yaptıklarını hakkıyla görendir (Enfâl, 8/39). Onlarla savaşın ki, Allah onlara sizin ellerinizle azap etsin, onlarl rezil etsin, onlara karşı size yardım etsin, mü'min topluluğun gönüllerini ferahlatsın ve onların kalplerindeki öfkeyi gidersin (Tevbe, 9/14). Ĕger Allah yolunda sefere çıkmazsanız, sizi elem dolu bir azap ile cezalandırır (Tevbe, 9/39). Sakın za'f göstermeyin. Üstün olduğunuz halde barışa çağırmayın (Muhammed, 47/35). Ey Peygamber! Kâfirlere ve münafiklara karşı cihad et, onlara karşı sert davran. Onların varacă̆l yer cehennemdir (Tahrîm, 66/9).

İlk görüşte olanlara göre saldırı söz konusu olursa savunma sınırlarını aşmamak kaydıyla savaş yapmak meşrudur. Saldırı yapmadıkları müddetçe inkârcıları yok etmeye kalkışmak caiz değildir. Böylece denebilir ki onlar öteki değildir. İkinci görüştekilere göre ise küfrün kendisi bizzat savaş nedenidir. Kâfir, ortadan kaldırılması lazım gelen bir varlık olup ötekidir. Zira Allah katında kabul edilen tek din İslam'dır. Kim Íslam'dan başka bir din ararsa, (bilsin ki o din) ondan kabul edilmeyecek ve o ahirette hüsrana uğrayanlardan olacaktır (Âl-i İmrân, 3/85).

\subsubsection{Bir Arada Yasamanın Illkelerinin Konulması}

Müslüman olmayanları bir yönüyle öteki görüp onlarla ilişkileri sınırlandıran, hatta onlara savaş açmayı bile belli gerekçe ve kurallar çerçevesinde meşru gören Kur'an; aynı anda onlarla bir arada yaşamın kurallarını ortaya koymuştur. Hz. Muhammed, Medine'ye hicret edip orada hâkimiyet inşa ettikten sonra Medine ve civarını yurt olarak tanımlayan ve bu coğrafyada yaşayan Müslüman, ehlikitap ve müşrikleri diğer bölgelerde yaşayan insanlardan ayrı bir ümmet olarak değerlendiren bir sözleşme yapmıştır. Böylece sınırları belirlenen coğrafyadaki farklı kimliklerin bir arada yaşamaları garanti altına alınmıştır. 
İslam hukukçuları, temel dinî kaynakları esas alarak farklı inanç gruplarının bir arada yaşamalarının ilkelerini belirlemiştir. Özü itibarıyla farklı dinî gruplarının inanç hürriyetini, seyahat özgürlügünü, kamu hizmetlerinden istifade edebilme hakkını garanti altına alan, onlara can ve mal güvencesini sağlayan ve başkaca bazı vatandaşlık haklarına sahip olarak İslam diyarında yaşamalarına imkân veren bir hukuk söz konusudur. Bu hukuk, İslam fikhında ehlizimmet hukuku başlığıyla geniş bir yer almaktadır (İbn Hişam, 2009: 452-453; Zuhaylî, 1989: 442; Hamidullah, 2003: 175-210; Bardakoğlu, 2001: 21; Fayda, 2013: 428429; Sarıçam, 2014: 143-149; Şentürk, 2000: 328; Yaman, 2013: 435-437). Bu hukuka göre farklı din mensuplarının İslam diyarında yaşamaları mütekabiliyet ekseninde garantiye bağlanmıştır (Gündüz, 2012: 490). Ayrıca Kur'an, onların inançlarına hakaretamiz yaklaşmayı yasaklamış Onların, Allah'ı birakıp tapındıklarına sövmeyin, sonra onlar da haddi aşarak, bilgisizce Allah'a söverler (En'âm, 6/108) inanmayı özgür iradeye bağlamış, De ki: "Hak, Rabbinizdendir. Artık dileyen iman etsin, dileyen inkâr etsin." (Kehf, 18/29); "Sizin dininiz size, benim dinim de banadır." (Kâfirûn, 109/6) ve düşmana karşı dahi adil olmayı emretmiştir Bir topluma olan kininiz sizi adaletsizliğe itmesin. Adil olun (Mâide, 5/8). Bu suretle inanç hürriyetinin ilkelerini belirlemiştir.

Hulasa İslam'ın öteki olarak müşriklere yaklaşımı ne tamamen savaş endeksli olmuş ne de pasif barış parantezi içine alınmıştır (Yaman, 2008: 100-102). Müşrik, pislik olarak nitelendirilmesine rağmen Kur'an'da onlarla bir arada yaşamanın kuralları oluşturulmuştur. Kur'an ve sünnetin ortaya koyduğu ilkeler bir bütün olarak ele alınırsa hiçbir müşrikin şirkten dolayı öldürülmeyeceği açığa çıkacaktır. Aksine öldürülmeyi meşru kılan sebebin müşriklerin Müslümanlara karşı savaşa katılmalarıdır. (Esgin, 2014: 84). Ehlikitap ile dost olmayı yasaklayan İslam dini aynı anda onlara yaşam hakkı ve dinî özgürlükler vermiştir (Hökelekli, 2007: 411). De ki: "Hak, Rabbinizdendir. Artık dileyen iman etsin, dileyen inkâr etsin." (Kehf, 18/29). Sizinle savaşanlara karşı Allah yolunda siz de savaşın. Ancak aşırı gitmeyin. Çünkü Allah aşırl gidenleri sevmez (Bakara, 2/190). O halde kim size saldırırsa, size saldırdı ğ gibi siz de ona saldırın, (fakat ileri gitmeyin) (Bakara, 2/194).

Kur'an'ın ötekileştirici tutumunun Müslümanların zihin dünyasını etkilediği gibi bir arada yaşamın temel ilkelerini ortaya koyan kucaklayıcı yaklaşımı da İslami toplumda karş1lık bulmuştur. Müslümanlar, diğer semavi dinlerin kitap ve peygamberlerine iman etmiş, aksi yönde bir delil bulunmadığında diğer dinlerin mukaddes kitaplarında bulunan ahkâmın fikhî delil olduğuna hükmetmiş (İbn Teymîyye, "tarihsiz": 188-190; Aktan, 2008: 219) ve o dinlerin mensupları ile bir arada yaşamanın hukukunu oluşturmuştur. Zira Hz. Muhammed Medine'ye hicret edince ilk iş olarak oradaki Ensar, Muhacir, müşrik ve Yahudi gibi farklı toplumlar arasında karşılıklı hak ve vazifeleri bildiren bir barış ittifakı kurmuştur. Sonraki yıllarda Medine'de güçlü hale gelip hâkimiyet inşa etmesine rağmen Hz. Muhammed, çevredeki Hristiyan ve müşrik kabilelerle barış antlaşması yapmaya devam etmiş ve mecbur kalmadıkça onlarla savaşmamıştır. Böylece İslam'ın temel bir ilkesini; öteki ile ilişkileri mütekabiliyet esasına göre düzenlemiştir (Aydın, 2008: 677; Yeldan, 2012: 52).
Bu arada ifade edilmeli ki bir arada yaşam ilkelerinin sadece ehlikitap ile sınırlı olup olmadığı, müşrikleri kapsayıp kapsamadığı konusunda tartışmalar vardır. Bir görüşe göre zimmet anlaşması sadece kitap ehli olan gayrimüslimlerle sınırlıdır. Müşrikler ile zimmet akdi yapılamaz. Bu görüște neredeyse mezheplerin ittifakı söz konusudur (İbn Kudame, 1997: 31; Zuhaylî, 1989: 442-443; Yurdaydın, 1986: 97). Buna göre müşrikler öteki olup Müslümanlar ile ortak yaşam hakkına sahip değildir. Aklî ve naklî yönlerden daha kuvvetli görüşe göre ise her çeşit gayrimüslim ile zimmet akdi yapmak caizdir (Zeydan, 1994: 431). Eğer Allah'a ortak koşanlardan biri senden sığınma talebinde bulunursa, Allah'ın kelâmını ișitebilmesi için ona sı̆̆ınma hakkı tanı. Sonra da onu güven içinde olacă̆ yere ulaştır. Bu, onların bilmeyen bir kavim olmalarl sebebiyledir (Tevbe, 9/6) ayeti ve $\mathrm{Hz}$. Muhammed'in müşrikleri de kapsayan Medine sözleşmesi bu görüşü teyit eden delillerdendir (Nevevî, 1980: 168).

\section{2. Öteki Cins}

Her birisinin kendisine mahsus özelliklerinin bulunduğu kadın ile erkeğin birbirleriyle ilişkileri, kadın veya erkek cinsinin toplumsal hayatta işgal ettiği konumu ve toplumdan topluma farklılık arz eden karşı cinse bakış açısı tarih boyunca sorunlu olagelmiştir. Hemen her din, inanç sistemi, düşünce akımı vs. kendince bu sorun konu hakkında perspektif ortaya koymaya çalışmıştır. Konuyu ayrımcı bir mantıkla; "Ben-Öteki" diyalektiğinde ele alıp kadını ötekileştiren, değersiz gören ve neredeyse kadını erkeğin mülkü olarak değerlendiren ataerkil anlayış (Sibaî, 2010: 11 18; Botî, 1996: 46-47; Durmuşoğlu vd., 2008: 622-623), din mensuplarını da bir şekilde etkilemiştir. Hatta Müslüman, Hristiyan, Yahudi, Budist, Hindu vb. dinî gruplar içerisinde toplumsal cinsiyet meselesine en fazla tutucu yaklaşan ve kadını ötekileştiren kitlenin Müslümanlar (Toprak vd., 2010: 88) olduğu konusunda bir alg1 vardır. Müslümanlara dönük oluşan söz konusu bu algının sübjektif boyutu araştırmamızın konusu değildir. Bizim amacımız Müslümanların bu konudaki zihin dünyasını etkileyen veya şekillendiren etkenler arasında İslami kültürün rolünü ve Kur'an'ın gerçek yaklaşımını açığa çıkartmaktır.

\subsubsection{Kadının Yaratılıșta Tali Olması}

Kadını öteki gören anlayış, ötekileştirme sürecini erkek için yaratılan, şeytan ile işbirliği yapan ikincil varlık olan Havva ile başlatır (Durmuşoğlu vd., 2008: 631). Kur'an'da ilgili mesele hakkında açık bir ifade bulunmamasına rağmen müfessirlerin çoğu kadının erkek için ve erkeğin en eğri olan kaburga kemiğinden yaratıldığını ifade eder. $\mathrm{Bu}$ görüştekilere göre yaratıldığı kaynak eğri olduğu için kadınların düzelmeleri mümkün değildir. Bunlara göre kadın zayıf karakterlidir. İradesi zayıf olduğu için aslında kadının mükellef olmaması gerekir. Sırf erkeğe itaat etsin diye kadın mükellef kılınmıştır. Aynı zamanda bunlara göre Havva şeytana uyduğu için kadınlar, ceza olarak regl dönemi ile hamilelik sancısı yaşamaktadır. (Durmuşoğlu vd., 2008: 627-630). Bazı kimseler, kadının dünyanın en büyük fitnesi olduğunu iddia etmiştir. Hatta kadınları yüksek binalara yerleştirmeyi ve okuma yazma öğretmeyi yasaklayan bir hadisin olduğunu iddia edenler olmuştur. Aslında sahih olmayan söz konusu rivayeti de bu iddia sahipleri şöyle gerekçelendirmiştir: Kadınlar, yüksek binalara 
yerleştirilirlerse erkekleri dikizlerler, yazı yazmayı öğrenirlerse gizli sevgilileriyle mektuplaşırlar (Kurtubî, 2006: 379-380; Şirbinî, 2004: 649-650; Durmuşoğlu vd., 2008: 631).

Yaratış ile alakalı bu tür anlatım ve yorumlar aslında Kur'an'a dayanmayan erkek merkezli yorumlardır. Zira Kur'an'a göre kadın ve erkeğin yaratıldığı kaynak aynıdır. Ey insanlar! Sizi bir tek nefisten yaratan ve ondan da eşini yaratan; ikisinden birçok erkek ve kadın (meydana getirip) yayan Rabbinize karşı gelmekten sakının (Nisâ, 4/1). Allah sizi bir tek nefisten yaratan ve kendisi ile huzur bulsun diye eşini de ondan var edendir (A'râf, 7/189). Kadının erkeğin kaburgasından yaratıldığı meselesi ise Tevrat gibi başka kaynaklardan İslami literatüre geçmiştir (Kurtubî, 2006: 408-411; Şirbinî, 2004: 623; İbn Aşur, "tarihsiz": 210; Merağî, 1985: 137; Öztürk, 2013: 173; Salmazzem vd., 2014: 233). Kur'an; kadını, kadın-erkek ikilemine indirgemeden ve cinsiyet ayrımcılığına gitmeden insan oluşuyla ele alır. Zira Kur'an, insanın yaratılışının başlangıcını anlatan kıssada yaratılacak varlığın erkek veya kadın oluşunu değil, "beşer"1 ve "halife"2 oluşunu zihinlere sunmaktadır. İlahi kudret tarafından halifelik payesiyle onurlandırılan, insanlıkta kemale erebilecek yeteneklerle donatılan $^{3}$ kadın ve erkeğin sorumlulukta eşit olduğuna Kur'an'da birçok kez vurgu yapılmıştır (Durmuşoğlu vd., 2008: 626). Keza, Erkek veya kadın, kim mü'min olarak iyi iş işlerse, elbette ona hoş bir hayat yaşatacağız ve onların mükâfatlarını yapmakta olduklarının en güzeli ile vereceğiz (Nahl, 16/97) ayetinde geçen "erkek" ve "kadın" kelimeleri umumi manada kullanılmıştır. Böylece kadın ile erkeğin yaratılışta olduğu gibi mükellefiyette de eşit olduğuna işaret edilmiştir (Şirbinî, 2004: 290; Alusî, 2005: 286; Çelik, 1995: 89-90).

\subsubsection{Kadının Medeni Haklarda Kısıtlı Olması}

Kadını öteki gören anlayış, evlilik başta olmak üzere birçok medeni hakta kadının kısıtlı sahip olduğunu iddia eder. Bunu da kendilerince yorumladıkları "nas"lara dayandırır. Buna göre kadın öteki olarak erkeğin sahip olduğu bütün haklara sahip değildir.

Kadınların erkeklere göre kısıtlı haklara sahip olduğu iddia edilen konuları birkaç başlık altında ifade etmek mümkündür.

\subsubsection{Kadinın Eve Hapsedilmesi}

Kadınları sosyal hayattan, medeni aktivitelerden, iktisadi ve siyasi faaliyetlerden soyutlamak isteyen anlayış bunun için kadınlara bazı kısıtlamalar getirmek istemiştir. Buna göre kadının evinden dışarıya çıkması ve seyahat hakkı kısıtlıdır. Erkeğin izni ve refakati olmadan kadın ibadet için dahi dışarı çıkmaması lazımdır (Durmuşoğlu vd., 2008: 636). Evlerinizde oturun. Önceki cahiliye dönemi kadınlarının açılıp saçıldı ̆̆ gibi siz de açılıp saçılmayın (Ahzâb, 33/33). Zira erkeğin görevi kadını eve kapatmak, kadının görevi ise erkeğine itaat etmektir (Durmuşoğlu vd., 2008: 641). Kadının, ancak yakınlarının veya bir grup kadının olduğu bir ortamda sefere çıkması caizdir; tek başına sefere çıkması ise haramdir (Zuhaylî, 1989: 32-36). Hatta fitneye sebep olur kaygısıyla güzel ve cazibeli kadınların camiye girmeleri mekruh sayılmıştır (Zuhaylî, 1989: 153-155 ile 365).
Hâlbuki eve hapsetme anlamındaki ayetin devamında ifade edildiği üzere bu durum, cahiliye döneminde kadınların vücutlarının bir kısmını açıkta bırakacak şekilde parıltılı elbiseler giyip erkeklerin dikkatini çekmeye çalışmaları ve teşhircilik yapmalarıyla alakalıdır. İlgili ayet, kadının eve hapsedilmesi gibi bir hüküm içermemektedir. Bir görüşe göre de emir yine teşhircilik kaydıyla Hz. Peygamber'in hanımlarına mahsustur. Zaten Hz. Muhammed'in hanımları dâhil olmak üzere Müslüman kadınlar hem O'nun döneminde hem de vefatından sonra herhangi bir itirazla karşılaşmadan savaş ve seferlere katılmışladır (Maturidî, 2005: 340; Kurtubî, 2006: 141; Kasimî, 2003: 68; İbn Aşur, “tarihsiz": 10-12; Şimşek, 2012: 187; Ateş, 1989: 155-156). İslam'ın ilk döneminde kadınların ilmî faaliyetlere katılması, çarşı, pazar, düğün ve etkinliklere iştirak etmesi ya da ibadet için camiye girmesi konusunda bir kısıtlama söz konusu olmamıştır. Bu konuda kadınların kısıtlandığına dair bir ayet yoktur. Ayrıca Hz. Muhammed'in gece vakti dahi kadınların camiye girmelerinin engellenmemesine dair özellikle vurgusu vardır (Buharî, 1980: Kitabu'l-Ezan, 10/162-865; Botî, 1996: 63-64 ile 82-89).

\subsubsection{Kadına Şiddet}

Kadın erkek ilişkisini hiyerarşik bir muhtevada tasavvur eden ve bu ilişkide erkeği itaat edilmesi lazım gelen bir konumda gören anlayış, erkeğe itaat noktasında kadınlara yükümlülükler bindirmiştir. Buna göre kadının erkeğe itaat etmek zorunludur. Kadınını itaat etmediği zaman erkeğin ona öğüt vermesi lazımdır. Nasihatin fayda vermediği durumda ise erkeğin kadına şiddet uygulaması caizdir. (Evlilik yükümlülüklerini reddederek) başkaldırdıklarını gördügünüz kadınlara ögüt verin, onlarl yataklarında yalnız bırakın. (Bunlar fayda vermez de mecbur kalırsanız) onlart (hafifçe) dövün (Nisâ, 4/34). Bu ayetin nüzul sebebi ile ilgili şöyle bir rivayet vardır: Bir sahabenin eşini dövmesi üzerine ilgili kadının babası, kızını alarak şiddet uygulayan erkeği Hz. Muhammed'e şikâyet etmesi üzerine Hz. Muhammed, eşini döven kişiyi kınamış ve onu cezalandırmak istemiştir. Bunun üzerine yukarıdaki ayet nazil olmuş ve $\mathrm{Hz}$. Muhammed "ben bir şey irade ettim, Allah Başka bir şey irade etti, şüphesiz O’nun iradesi daha hayırlıdır” dedi.

Mezhep imamlarının büyük çoğunluğu, İslami kaynakların bir bütün olarak değerlendirilmesinden yola çıkarak kadınların dövülmemesinin esas olduğunu söyledikten sonra ayette geçen "dövün” kelimesini delil göstererek kadınların hafifçe dövülebileceğini söylemiştir. Hatta Hanbeli ve Maliki mezhebine göre dövmek caiz olduğu için bu esnada dövme nedeniyle kadının ölmesi durumunda erkeğin diyet ödemesi veya cezalandırılması gerekmez. Bazı alimler, kadınların hafifçe dövülmesinin normal karşılanması gerektiğini ve bunun eleştirilecek bir konu olmadığını söylemişler (Ebu Hayyan, 2010: 248; Şirbinî, 2004: 346; Ebu's-Suud, 2010: 200; Kasimî, 2003: 97; Riza vd., 2005: 59-61; Zuhaylî, 1989: 339-340).

Oysa ayette geçen "darb" kelimesinin yaygın anlamı "dövmek" olsa da bu kelimenin ilgili ayette "dövme" manasında olmadığına dair bazı görüşler de vardır (Aydın, 2001: 89-90). Ayetteki "darb" kelimesi dövmek manasında olduğunu söyleyen birçok âlim, dövmek eylemini "mendil veya misvak ile dövmek" şeklinde izah etmek suretiyle bunun şekli olduğunu ortaya koymuştur. Ayrıca her ne kadar mendil gibi nesneler ile acıtmadan dövmeye izin olsa da asıl 
ve erdemli olanın dövmemek olduğu konusunda görüşler vardır (Maturidî, 2005: 209; Kasimî, 2003: 98; Kutub, 2008: 654; Şimşek, 2012: 503). Keza Hz. Peygamber'in öğretisi ve uygulamaları dikkate alınırsa şiddetin bir çözüm şekli olmadığı anlaşılacaktır. Zira ahlakı Kur'an olan (Müslim, 2006: Kitabu Salati'l-Musafirin ve Kasriha, 6/139-746) ve icraatı Müslümanlara örneklik teşkil eden (Ahzâb, 33/21) Hz. Muhammed hiçbir şekilde kadınlara şiddet uygulamamış ve uygulayanları kınamıștır (Buharî, 1980: Kitabu'n-Nikah, 67/92-5204; Müslim, 2006: Kitabu'l-Fedail, 19/79-2328; Durmuşoğlu vd., 2008: 644). Aynı şekilde Kur'an, kadın ile erkeğin ilişkisinin sevgi ve merhamete dayalı olmasını emretmiştir: Ĕger bir kadın kocasının, kendisine kötü davranmasından yahut yüz çevirmesinden endişe ederse, uzlaşarak aralarını düzeltmelerinde ikisine de bir günah yoktur. Uzlaşmak daha hayırlıdır. Nefisler ise kıskançlı̆̆a ve bencil tutkulara hazır (elverişli) kılınmıştır. Eğer iyilik eder ve Allah'a karşı gelmekten sakınırsanız, şüphesiz Allah yaptıklarınızdan haberdardır (Nisâ, 4/128). Kendileri ile huzur bulasınız diye sizin için türünüzden eşler yaratması ve aranızda bir sevgi ve merhamet var etmesi de onun (varlığının ve kudretinin) delillerindendir (Rûm, 30/21). Ey iman edenler! Kadınlara zorla mirasçı olmanız size helal değildir (Nisâ, 4/19). Bütün bu deliller göstermektedir ki İslam dini, her ne kadar kadının hafifçe dövülmesine istisnai bir hal olarak izin vermiş olsa da bunu tasvip etmemekte, sevgi ve şefkate dayalı bir ilişkiyi benimsemektedir.

\subsubsection{Evlenme ve Boşanma Hakkı}

Evlilik akdini gerçekleştirme ve sonlandırma konusunda kadın kısıtlıdır. Kadın, velisinin izni olmadan evlilik yapamaz. Ancak velisi onu evlendirebilir. Velisinin de erkek olması lazımdır. Zira kadınların aklı kıttır, şehvetleri fazladır. Bu nedenle yanlış bir eş seçmek suretiyle velisinin yüzünü kara çıkarabilir. $\mathrm{Bu}$ görüşte olanlar, Kadınları boşadığınız ve onlar da bekleme sürelerini bitirdikleri zaman kendi aralarında aklın ve dinin gereklerine uygun olarak güzellikle anlaştıkları takdirde, eşleriyle (yeniden) evlenmelerine engel olmayın (Bakara, 2/232) ayetindeki "engel olmayın" ifadesini, erkeğin bu konuda engel olabilme hakkına sahip olduğunun göstergesi olarak yorumlamışlar. Ayrıca Sizden bekâr olanları, kölelerinizden ve cariyelerinizden durumu uygun olanları evlendirin (Nûr, 24/32) ile Iman etmedikleri sürece Allah'a ortak koşan kadınlarla evlenmeyin (Bakara, 2/221) ayetlerindeki hitabın erkelere yapılmış olmasını ve Hz. Muhammed'in "Nikâh, velisiz olamaz" vb. (Tirmizi, 1978: Hadis No: 1101 ile 1102, 398-399) hadislerini bu hakkın erkeklere verildiğine delil olarak göstermişler (İbn Hazm, "tarihsiz": 451-452 ile 469; Serahsî, 1989: 10-11; İbn Kudame, 1997: 345; Nevevî, 1980: 240-243; Karafî, 1994: 201). Bu görüştekilere göre kadının evlilik akdi yapması erkeğin iznine bağlı olduğu gibi kadının evlilik akdini sonlandırılması da kısıtlıdır. Erkeğin tek taraflı olarak kadını boşama hakkı vardır. Kadınları boşadığınız ve onlar da bekleme sürelerini bitirdikleri zaman, ya onlart iyilikle tutun yahut iyilikle bırakın (Bakara, 2/231). Ama kadının bu hakkı yoktur. Çünkü evin reisi erkektir. Nafaka ve mehir ücretini o ödemiştir. Boşama sonrası doğan mali yükümlülükleri ancak erkek karşılayabilir. Ayrıca kadın duygusal olduğu için kendisine boşama hakkı verildiği takdirde en ufak bir meselede boşama yoluna başvurması muhtemeldir (Zuhaylî, 1989: 347-348 ile 360; Durmuşoğlu vd., 2008: 641).
Oysa Ĕ̆er erkek karısını (üçüncü defa) boşarsa, kadın, onun dışında bir başka kocayla nikâhlanmadıkça ona helal olmaz (Bakara, 2/230) ile Kadınlar boşadığınız ve onlar da bekleme sürelerini bitirdikleri zaman kendi aralarında aklın ve dinin gereklerine uygun olarak güzellikle anlaştıkları takdirde, eşleriyle (yeniden) evlenmelerine engel olmayın (Bakara, 2/232) ayetlerinde "nikâh" fiili velisine değil kadına isnat edilmiştir. Bu demektir ki kadının kendisi evlilik akdini yapmaya muktedirdir. Ayrıca kadının evlilik akdini gerçekleştirebileceğine dair birçok sahih rivayet vardır. Velisinin izni olmadan kadının, evlilik akdini gerçekleştirmemesi içtihadı aslında sahih delillere dayanmayan ve üzerinde ittifak sağlanmayan bir yorumdur. Zira Hanefiler bu yorumu kabul etmemiştir (Serahsî, 1989: 12-13; İbn Kudame, 1997: 345; Karafî, 1994: 201; Sibaî, 2010: 43-44).

İslam'da birden fazla boşama şekli vardır. Erkeğe "talak" şekliyle tek taraflı boşama hakkı verilmişse, nikâh anında kadının şart koşması ve erkeğin de bunu kabul etmesi yöntemiyle veya kadının mehir anında aldığı ücrete karşılık olarak değerlendirebileceğimiz ücret karşılı̆̆ yoluyla kadına da aynı hak verilmiştir (Sibaî, 2010: 95; Ebu Zehra, "tarihsiz": 780; Zuhaylî, 1989: 360-361, 414-424 ile 480-482; Acar, 2010: 497; Atar, 2005: 339-340; Şimşek, 2012: 250). Ĕger onlar Allah'ın belirlediği ölçüleri gözetmeyecekler diye endişe ederseniz, o zaman kadının (boşanmak için) bedel vermesinde ikisine de günah yoktur (Bakara, 2/229). Öte yandan geçimsizlik durumunda tarafların hakemlere başvurmaları istenmiş ve hakemlerin bu konuda bir karar vermesi (Zuhaylî, 1989: 347; (Botî, 1996: 137) bir yöntem olarak sunulmuştur. Ĕ̆er kart-kocanın arasının açılmasından endişe ederseniz, erkeğin ailesinden bir hakem, kadının ailesinden bir hakem gönderin (Nisâ, 4/35).

Kur'an'da, kadın ile erkeği hukukta eşit olduğu ortaya konmuş olsa da boşama yetkisi erkeğe koşulsuz verildiği halde bu yetki kadına mahkeme yoluna başvurması, erkeğe rıza gösterecek miktarda ücret ödemesi veya nikâh anında erkekten izin almış olması ile koşullandırılmıştır. Ayetin devamındaki Yalnız erkeklerin kadınlar üzerinde bir derece farkı vardır (Bakara, 2/228) ifadesi buna yorumlanmıştır (Ebu Zehra, “tarihsiz": 768-769; Şimşek, 2012: 258 ile 249). Hulasa boşama konusunda kadın, erkeğin sahip olduğu bütün haklara sahip değildir. Ama onun da boşama hakkı vardır. Ayrıca boşama konusunda erkeğe avantaj sağlandığı gibi evlilik meselesinde mehir ve nafaka konusunda da kadına aynı şekilde avantaj sağlanmıştır (Botî, 1996: 135-136).

\subsubsection{4. Çok Eşlilik}

İslam'da erkeğin birden fazla kadın ile evlenmesi meşrudur. Ĕger, (velisi olduğunuz) yetim kuzlar (ile evlenip onlar) hakkında adaletsizlik etmekten korkarsanız, (onları değil), size helâl olan (başka) kadınlardan ikişer, üçer, dörder olmak üzere nikâhlayın. Ĕger (o kadınlar arasında da) adaletli davranmayacağınızdan korkarsanız o takdirde bir tane alın (Nisâ, 4/3). Ayette birden fazla kadın ile evlenmek adalet şartına bağlanmış olsa da "kişinin adaletli davranmayacağı durumlarda bile yaptığı birden fazla evlilik geçerlidir" (Maturidî, 2005: 13-14) şeklinde hâkim görüş vardır. İslam coğrafyasında tarih boyunca uygulanagelen ve günümüzde de az çok yaygın olan birden fazla kadın ile evlilik yapmak durumu normal karşılanmaktadır. Hatta 
bunun gerekli bir şey olduğunu ortaya koyanlar olmuştur. Kadınların sayısının savaş veya başka nedenlerle erkeklerin sayısında fazla olduğu durumlarda içtimai saiklerle, kadının kısır olması veya erkeğin cinsel arzularını yerine getirmekte yetersiz kalması ya da erkeğin sık sık seyahate çıkması gibi ferdî nedenlerle birden fazla kadın ile evlenmenin zorunlu hale gelebileceğini ifade edenler olmuştur (Sibaî, 2010: 57 59). Fakat tersi olursa yani erkek sayısı fazlalaşırsa ya da erkek tarafi kocalık vazifesini yerine getiremez duruma gelirse kadının birden fazla erkek ile evlenmesi caiz olmaz. Zira bu hem maslahata hem de hayatın olağanlığına aykırıdır. İslam dini, bunu kesinlikle kabul etmez (Botî, 1996: 133-134).

Oysa çok eşlilik Yunan, Çin, Hint, Babil, Asur ve Mısır medeniyetlerinde olan bir evlilik şeklidir. Hatta söz konusu medeniyetlerde belli bir sınırlama ve ilke mevcut değildir. İslam dini bu fiili durumu önemli ölçekte 1slah etmiş ve çok eşlilik ile ilgili ayettin devamında ifade edildiği gibi esas olanın tek eşlilik olduğunu, çok eşliliğin şarta bağlı ve istisnai bir durum olduğunu açık bir şekilde ortaya koymuştur. Kısacası, İslam dininin tercih ve tavsiye ettiği tek eşliliktir. (Ebu's-Suud, 2010: 163; Sibaî, 2010: 48-50 ile 63; Zuhaylî, 1989: 169; Şimşek, 2012: 472). İslam âleminde çok eşliliğin yaygın olması ve bu konuda şartlara riayet edilmemesi işin esasıyla ters düşmektedir. Ezcümle şarta bağlı olsa da, tek eşlilik esas olsa da İslam'da çok eşliliğe cevaz verilmiştir. $\mathrm{Bu}$ da adalet şartına riayet etmeden ve istisnai halleri gözetmeden aynı anda birden fazla kadın ile evliliğin yaygınlaştırmasına sebep olmuştur.

\subsubsection{Kadının Şahitlikte Yarım Sayılması}

Kadının yetersiz görüldüğü konulardan birisi de şahitlik meselesidir. Zira kadın yaratılıșta tali, akıl ve karakterde yetersiz, şehvette aşırı olması nedeniyle şahitlikte erkeğin yarısıdır. Hatta ceza davalarında şahitliği hiç kabul edilmemektedir. Zira o, dili tutuk, aklı kıt ve fitraten ahmaktır. Zaten kadın yetersiz olduğu için kendisini süs püsle tatmin eder (Serahsî, 1989: 142-143; Şirbinî, 2004: 216; Durmuşoğlu vd., 2008: 633-634). (Bu işleme) şahitliklerine güvendiğiniz iki erkeği; ĕger iki erkek olmazsa, bir erkek ve iki kadını şahit tutun (Bakara, 2/282).

Hâlbuki şahitlik ayetinde ifade edilen iki kadının bir şahit sayılması meselesi vadeli borçlanma konusuyla mahsus olup istisnai bir durumdur ve kadınının unutması ile koşullandırılmıştır. Kadının unutması söz konusu olmasa bir kadının şahitliği yeterli ve eşdeğer olacaktır. Ayrıca sadece kadınların vakıf olabileceği konularda kadınların şahitliği kabul edilir (İbn Hazm, "tarihsiz": 397; Zuhaylî, 1989: 571 572; Durmuşoğlu vd., 2008: 633; Kırbaşoğlu, 1997: 263 264). Bazen de kadına değer verildiği için şahitliğinin kabul edilmediği söz konusu olabilir. Buna zina şahitliğini örnek gösterebiliriz (Zuhaylî, 1989: 48). Hulasa spesifik bazı konularda kadının şahitliğinin yetersiz sayılmasın nedeni kadının kişiliğiyle alakalı olmayıp tamamen objektif koşulların ortaya çıkardığı bir sonuçtur (Sibaî, 2010: 23). İslam dini, şahitlikte iki hususu göz önünde bulundurmaktadır: Brincisi şahidin adil ve hatırında tutabilme kabiliyetine sahip olması ikincisi ise ilgili olay ile şahitlik yapacak kişi arasında vukufiyet bağının bulunmasıdır. Bu nedenle vakıf olamayacağı konularda kadınların şahitliği kabul edilmediği gibi aynı şekilde erkeklerin de şahitliği kabul edilmez ((Botî, 1996: 147-148). $\mathrm{Bu}$ konuda temelde bir ayrımcılık yoktur.

\subsubsection{Kadının Mirastan Az Pay Alması}

Kadını mali anlamda kısıtlayan konulardan bir tanesi miras hukukudur. Nitekim miras hukukuna göre kadın kısıtlı olup bu konuda erkeğin sahip olduğu payın ancak yarısına sahiptir. Dişil olan yaratılışta zayıf, akılda yetersiz, aldanmaya elverişli, harcamada müsrif, hayır işlerinde cimri olduğu için mirasta yarım pay almaktadır (Durmuşoğlu vd., 2008: 635). Havva anamız, bir miktar buğdayı üçe bölüp iki payı kendisine bir payı Hz. Adem'e verdiği için Allah, durumu onun aleyhine çevirdi ve erkeğin hissesini iki katına çıkardı (Durmuşoğlu vd., 2008: 636). Allah size, çocuklarınız (-ın alacă̆ı miras) hakkında, erkeğe iki dişinin payı kadarını emreder (Nisâ, 4/11).

Oysa miras paylaşımında kadının erkek ile aynı oranda pay aldığı durumlar da vardır. Ana, baba ve akrabaların (miras olarak) biraktıklarından erkeklere bir pay vardır. Ana, baba ve akrabaların biraktıklarından kadınlara da bir pay vardır (Nisâ, 4/7). Ölenin çocuğu varsa, geriye biraktı̆̆l maldan, ana babasından her birinin altıda bir hissesi vardır (Nisâ, 4/11). Miras paylaşımında kadın ile erkeğin eşit pay aldığı durumlar olmakla birlikte ekseriyetle erkek iki kat pay almaktadır. Fakat bunun böyle olmasını etkileyen birçok faktör vardır. İslam'da ailenin geçim yükü, evlilik masrafı ve diğer mali sorumluluklar erkeğe yüklenmiştir. Kadın, evlenene kadar sadece kendi nafakasından sorumludur. Evlendikten sonra nafaka sorumluluğu erkeğe geçer. Bu gerçeklik ortadayken erkeğin mirastan fazla pay alması bir bütün olarak ele alınmadan ikiye bir formülüne indirgeyerek kadının ontolojik yetersizliğine ve cinsiyet ayrımcılığına yormak, erkeğin üstünlüğü ile izah etmeye çalışmak, kadının ötekileştirilmesine vesile kılmak yanlış bir yaklaşımdır. Hatta erkeğe daha fazla mali yük bindirdiği için İslami sistemde kadının kayırıldığı dahi söylenmiştir (Zemahşerî, 2009: 469-470; Şirbinî, 2004: 327; Kasimî, 2003: 38; Merağ̂̂, 1985: 196; Sibaî, 2010: 25-26; ; Şankitî, 2006: 241; Mevdudî, 1997: 333; Botî, 1996: 106-109; Aydın, 2001: 90; Durmuşoğlu vd., 2008: 636; Şimşek, 2012: 480-481). Ayrıca Hint, Çin, Germen ve Avrupa'nın diğer topluluklarında kadına mülk edinme hakkı verilmediği gibi mirastan pay alma hakkı da verilmezdi (Botî, 1996: 49). Keza cahiliye döneminde miras sadece savaşabilen erkelere verilirdi. Kadınlar tamamen mirastan mahrum birakılırdı. İslam'ın gelmesiyle birlikte bu konu hakkında Hz. Muhammed'e birçok şikâyet yapılması üzerine kadınların pay sahibi olduğunu bildiren yukarıdaki ayet nazil olmuştur (Maturidî, 2005: 40; İbnu'l-Cevzî, 2010: 378; Kurtubî, 2006: 97-98; Merağî, 1985: 195; İbn Aşur, “tarihsiz": 247-248; Mevdudî, 1997: 333). Söz konusu ayet ile kadın ilgili toplumda ilk defa mülk edinme ve mirastan pay alma hakkına sahip olmuştur. $\mathrm{Bu}$, tarihsel süreç içerisinde kıymetli bir atılımdır.

Hulasa kadını ötekileştiren zihniyet, özellikle miras meselesini öne sürerek bunu İslami kaynaklara dayandırma çabası vardır. Oysa bu, Kur'an'ın yaklaşımını ortaya koymamaktadır. Nitekim delil olarak sunulan ayetlerin ortaya koyduğu hüküm ve amaç başkadır.

\subsubsection{Kadının Cinselliğini Metalaştırmak}

Kadın ve erkek arasındaki cinsiyet farklılığını cinsiyet ayrımcılığına dönüştürmek, kadını cinsel meta olarak 
görmek ötekileştirmenin bariz bir tezahürüdür (Durmuşoğlu vd., 2008: 632). Ataerkil düşünceye sahip olanlara göre İslam dininde erkekten alınıp kadına verilen mehir ücreti, kadının cinselliğinden istifade etmek (Zemahşerî, 2009: 532; Şirbinî, 2004: 324) ve cinselliğine malik olmak içindir. Çünkü mehir, tam da kadının cinselliğinin fiyatıdır. Hatta kadının tam olarak mehir ücretine sahip olabilmesi için erkeğin, onun cinsel organından istifade etmesi lazımdır. Öpmek veya livatada bulunmak mehir ücretini tam olarak elde etmesine kâfi değildir (Serahsî, 1989: 64; İbn Kudame, 1997: 99-151-169-186-187 ). Böylece kadın-erkek ilişkisinde karşı cins olan kadın, erkeğin zevk objesine dönüşür (Durmuşoğlu vd., 2008: 638-640). Ey Peygamber! Biz sana mehirlerini verdiğin eşlerini... helal kıldık (Ahzâb, 33/50). Kadınlara mehirlerini (bir görev olarak) gönül hoşluğuyla verin (Nisâ, 4/4). Kadını tamamen cinsel meta olarak gören bu yaklaşım aynı anda kadını ötekileştirmektedir.

Oysa evlilik akdinde erkekten alınıp kadına verilen maddi veya manevi değer olan mehir, bazı geçmiş kavimlerde satın alma niteliğini taşısa da İslam dininde durum öyle değildir. Bunun aksine İslam'da mehir; kadın ile erkek arasında sadakat bağını kuvvetlendirmek, kadını ekonomik olarak güvenceye almak, onu sevindirmek ve erkeğin ona karşı iyi niyetli olduğunu ortaya koymak için olup kadına verilmiş bir haktır (Nevevî, 1980: 3-5; Zuhaylî, 1989: 251-253; Aydın, 2003: 389; Durmuşoğlu vd., 2008: 638; Yadsıman, 2003: 110; Şimşek, 2012: 474).

\subsubsection{Kadının Yönetici Olamaması}

Kadının erkeğe göre yetersiz olduğunu düşünen kesim, Peygamberlik ve devlet başkanlığı gibi toplumun yönetimiyle alakalı kurumların erkeklere mahsus olduğunu iddia eder. İtikat mezheplerinden olan Mâturidîliğe göre peygamberlik erkeklere mahsustur. Kadınların peygamber olması caiz değildir. Eşarîlere göre ise kadınların peygamber olması caiz fakat fiilen vaki değildir (Gölcük vd., 1998: 59; Durmuşoğlu vd., 2008: 635-642). Bu görüşte olanlara göre kadınlar bu görevleri yapamaz. Zira kadın-erkek ilişkilerinde erkeğin kadın üzerinde hükümranlık hakkı vardır; kadını yönetme hakkı erkeğe verilmiştir. Erkekler, kadınların koruyup kollayıcılarıdırlar. Çünkü Allah insanların kimini kiminden üstün kılmıştır. Bir de erkekler kendi mallarından harcamakta (ve ailenin geçimini sağlamakta)dırlar. Iyi kadınlar, itaatkârdırlar (Nisâ, 4/34). Erkek, vehbî ve kesbî olarak kadından üstündür. Zira Allah erkeği fitrî, insani, dini, ailevi, hukuki, ahlaki, siyasi, iktisadi vs. olarak kadına üstün kılmıştır (Maturidî, 2005: 199-202; Şirbinî, 2004: 346; Ebu's-Suud, 2010: 199; Kasimî, 2003: 96-98; Riza vd., 2005: 55; Durmuşoğlu vd., 2008: 640). Dolayısıyla onun erkeği yönetmesi işin tabiatına aykırı olup mümkün değildir. Şafii, Hanbeli ve Maliki mezhebine göre kadın "kadı" dahi olamaz. Bunu, Hz. Muhammed'in "Kadını yönetici yapan kavimler iflah olamaz" (Buharî, 1980: Kitabu'l-Meğazî, 64/82-4425) manasında bir hadisine dayandirırlar. Bu konuda sadece Hanefi mezhebinin görüşü farklıdır. Onlara göre kadın "kadı" olabilir. Ama kadının devlet başkanı veya halife olamayacağı hususunda bütün mezheplerin ittifakı vardır. Çünkü bu görev, kadının taşıyamayacağı kadar ağırdır (İbn Hazm, “tarihsiz”: 360; Sâbûnî, 2005: 119; İbn Kudame, 1997: 12-13; Nevevî, 1980: 319-322; Karafî, 1994: 16 ile 22; Sibaî, 2010: 28-30; Zuhaylî, 1989: 482 ile 693;
Botî, 1996: 69 ile 79). Bu yaklaşım kadını yönetimde ötekileştirmektedir.

Oysa Kur'an'a göre kadının erkeğe karşı yükümlülüğü erkeğin ona karşı yükümlülüğüne eşittir. Kadınların, yükümlülükleri kadar meşru haklarl vardır (Bakara, 2/228). Keza ayette geçen "kavvamlık" tamamen erkeğe yüklenen bir sorumluluktur. Bunu, ontolojik olarak erkeğin hükümranlık hakkı ve üstünlüğü ile izah etmek yanlıştır (Botî, 1996: 98; Durmuşoğlu vd., 2008: 643; Kırbaşoğlu, 1997: 260). Ayrica Hz. Muhammed, "Erkek ve kadının her ikisinin aileden sorumlu olduğunu” (Buharî, 1980: Kitabu'lAhkâm, 93/1-7138) ifade etmek suretiyle yönetme işinde kadın ve erkeğin eşit olduğunu ortaya koymuştur.

Kısacası Kur'an, kadın ile erkeğin ilişkisini hiyerarşik, ötekileştiren ve dikotomik bir ilişki olarak değil yeryüzünde halifelik ile görevlendirilmiş eşit varlıkların müsavi ilişkisi olarak görmektedir. Fakat bu eşitlik aynılık anlamına gelmez. İslam dini, cinsel farklılıkları göz ardı etmez. Devlet başkanlığı gibi hususi bazı meselelerde objektif şartlardan ötürü erkeğe öncelik verilmesi eşitlik ilkesini ihlal etmez. Zaten devlet başkanlığı dişındaki görevlerde erkeğin bir önceliği yoktur (Botî, 1996: 39-41 ile 69-71; Durmuşoğlu vd., 2008: 640).

\subsection{Farklı Cinsel Kimliklerin Ötekileștirilmesi}

Cins ayrımcılığı hakkında Kur'an'ın yaklaşımını ifade ederken bir konuya temas etmek lazımdır. Kadın veya erkeği birer cins olarak ayrımcılığa tabi tutmayan Kur'an; sapık bir cinsel eğilim olarak gördüğü eşcinselliği ise tamamen ret etmek suretiyle ötekileştirmektedir. Lût'u da Peygamber olarak gönderdik. Hani o kavmine şöyle demişti: "Sizden önce âlemlerden hiçbir kimsenin yapmadiğl çirkin işi mi yapıyorsunuz?" "Hakikaten siz kadınları birakıp, şehvetle erkeklere yaklaşlyorsunuz. Hayır, siz haddi aşan bir toplumsunuz." (A’râf, 7/80-81). Kavmi, (konuklarlyla çirkin ilişkide bulunmak üzere) ona doğru koşa koşa geldiler. Zaten onlar önceden de bu tür çirkin işleri yapıyorlardı. (Azap) emrimiz gelince oranın altını üstüne getirdik. Üzerine de Rabbinin katında işaretlenmiş pişirilmiş balçıtan taşlar yağdırdık. Bunlar zalimlerden uzak değildir. (Hûd, 11/78 ile 82-83). Lût'u da (Peygamber olarak gönderdik.) Hani o kavmine şöyle demişti: "Göz göre göre o çirkin işi mi yapıyorsunuz?" "Siz kadınları birakıp şehvetle erkeklere mi varlyorsunuz? Doğrusu siz ne yaptığını bilmez bir toplumsunuz." (Neml, 27/54-55). Yukaridaki ayetlerden anlaşılacağı gibi homoseksüelliğin erkeğin erkekle birlikte olduğu şekli tarih boyunca ilk kez Hz. Lut (a.s.)'un kavmi olan Sodom halkında ortaya çıkmıştır (Mevdudî, 1997: 59; Sabunî, 2001: 423-424). Kur'an'da bu kavmin işlediği günah, çirkin olarak tanımlanmış, o kavim "kendini bilmez topluluk" olarak kötülenmiş ve o kavmin korkunç bir şekilde yok edildiği ifade edilmiştir. Böylece kadın erkeğe veya erkeğin kadına meşru dairede cinsel ilgi duyması İslam tarafından tek doğru yol olarak ortaya konmuş; bunun dışında kalan eşcinsel eğilim ise haram olarak belirlenmek suretiyle ötekileştirilmiştir.

İnsanın erkek ve kadın olmak üzere birbirinden farklı ve birbirini tamamlayan çift yaratılmasının gayesi üreme ve neslin devamını sağlamak, böylece medeni hayatın çekirdek yapısı olan aile kurumunu tesis etmektir. Bunu sağlamanın yegâne yolu kadın ile erkeğin her türlü sapkınlıktan uzak bir 
şekilde birliktelik inşa etmesidir. Kur'an, bunu tek meşru yol olarak görmektedir. Bundan sapıp sırf cinsel tatmin için farklı eğilimlere girmek; akıl, fitrat ve lezzet sınırlarını ihlal, doğaya ihanet, insanlığa karşı suç, insan vücudunun fitrî vazifelerine tecavüz ve topluma karşı sorumsuzluktur. Bundan ötürü bu cerimeyi işleyen topluluk Allah tarafından sert bir şekilde kınanmış ve o topluluk taş yağmuruna tabi tutulmak ve altı üstüne getirilmek suretiyle kökünden kazınmıştır (Kurtubî, 2006: 185; Alusî, 2005: 51-52; İbn Aşur, "tarihsiz": 232; Merağ̂̂, 1985: 205; Ebu Zehra, “tarihsiz": 3737; Mevdudî, 1997: 59-61; Havva, 1990: 223).

Hulasa farklı cinsel eğilimlere yönelen kesimler Kur'an'a göre ötekidir. Zira bu, Allah'ın hükmüne ve hikmetine aykırıdır (Zemahşerî, 2009: 361; Kasimî, 2003: 498). İslam fikhına göre onların cezası ise kılıç ile veya yakarak öldürmektir (İbn Aşur, "tarihsiz": 232-233; Mevdudî, 1997: 63).

\subsection{Etnik Farkl11ık Yüzünden Ötekileştirme}

Günümüzde dünyanın siyasi şekillenmesini oluşturan ulusdevlet (Habermas, 2013; 13) sisteminin unsurlarından birisi olan "millet" kavramı, bu kavram etrafinda şekillenen ortak bilincin oluşturduğu ötekileştirme, İslam âleminin iç ilişkilerini etkilemektedir. Milliyetçilik, 1rkçılık, üstünlük iddiası ve diğer ulusları küçümseyen anlayış ilişkileri sorunlu hale getirmektedir. İslam âleminde bazı $\mathrm{rk}$, aile, kabile mensuplarının diğerlerinden üstün olduğuna dair bir alg1 vardır. Örneğin Hz. Muhammed'in Arap kavminden olması ve Kur'an'ın Arapça indirilmesi gibi realite Arapların üstün bir kavim olduğuna delil gösterilmiştir. İlk dönem İslam yöneticilerinin Haşemi ya da Kureyşi olması fiili durumundan ve Hz. Muhammed'in bu fiili durumu ifade eden söyleminden yola çıkarak yönetme işinin bu ailelere mahsus olduğuna hükmedilmiştir. Bu yaklaşım doğal olarak diğer kavim ve aileleri bu manada ötekileştirmektedir. Hatta bu yüzden İslam toplumuna hiyerarşik ve ötekileştirici bir anlayış yerleştiği söylenebilir. Örneğin bu coğrafyanın en sahipsiz, en mülksüz, en yurtsuz kesimi olan Romanlar, Osmanlı döneminde "buçuk millet" (Toprak vd., 2010: 110111) olarak nitelendirilmiştir. Coğrafyamızda diğer milletleri küçümseyen, onları ötekileştirip düşmanlaştıran bir yaklaşım vardır.

Kur'an ise insanlar arasındaki farklılıklarından ziyade varlık olarak ortak noktalarını ön plana çıkartmakta, günümüzde 1rkçılık olarak tanımlanabilen asabiyeti cahiliye adetlerinden saymakta, insanların köken eşitliğine vurgu yapmakta ve farklılıkların çeşitli etkileşimlerle sonradan oluştuğunu gözler önüne sermektedir (Gündüz, 2012: 486). Hani inkâr edenler kalplerine taassubu, cahiliye taassubunu yerleştirmişlerdi (Fetih, 48/26). Ey insanlar! Sizi bir tek nefisten yaratan ve ondan da eşini yaratan; ikisinden birçok erkek ve kadın (meydana getirip) yayan Rabbinize karşı gelmekten sakının (Nisa, 4/1). Ey insanlar! Şüphe yok ki, biz sizi bir erkek ve bir dişiden yarattık ve birbirinizi tanımanız için sizi boylara ve kabilelere ayırdık. Allah katında en değerli olanınız, O'na karşı gelmekten en çok sakınanınızdır (Hucurat, 49/13). Hz. Muhammed'in “Arap'in Arap olmayana üstünlüğü yoktur” (İbn Hanbel, 2001: Hadis No: 23489), "Kim cahiliye asabiyeti uğruna savaşır ve ölürse cahiliye üzeri ölmüştür" (Müslim, 2006: Kitabu'l-İmare, 33/53) ve "Allah, sizin dış görüşünüze ve malınıza bakmaz; ancak kalbinize ve işinize bakar" (Müslim, 2006: Kitabu'l-
Birr, 45/33) hadisleri İslam'ın ırkçılığa yaklaşımı konusunda ders niteliğindedir. Keza o dönemin zihin yapısına göre eşraftan sayılan birçok Kureyşlinin bulunduğu bir ortamda Hz. Muhammed'in azatlı bir köle olan Zeyd (r.a.)'i ve âmâ bir sahabe olan İbn Ümmi Mektum (r.a.)'ü defalarca kendisine vekil tayin etmesi ve "Başınızda Habeşli bir köle dahi olsa ona itaat edin" (Buharî, 1980: Kitabu'l-Ahkam, 93/4-7142) hadisi İslam'ın bu konuya yaklaşımını ortaya koymaktadir.

Hulasa Kur'an, insanın tercihine göre şekillenmeyen etnisite, dil, renk gibi aidiyetlerinden ötürü insanları sorumlu tutmaz, insanları bunlardan dolayı ötekileştirmez. Kur'an, insanın tercihine göre şekillenen inanç ve yaşam biçimi gibi kimliklerinden ise insanı sorumlu tutar (Bilgin, 2001: 11).

\subsection{Engellilere Yaklaşım}

Üretim ilişkilerinden tutun kaba kuvvete kadar birçok unsur, toplumsal yapının şekillenmesinde etkili olmaktadır. Tarih boyunca birçok toplumda içtimai hayat dizayn edilirken o gün itibarıyla geçer akçe neyse ona göre toplumun ana iskelesi oluşturulmuş ve başta engelliler olmak üzere dezavantajlı kesimler ötekileştirilmiştir.

İslam dini, dezavantajlı olanı ötekileştirmez, toplumun dışına itmez ve hakkının zayi edilmesine müsaade etmez. Aksine diğer insanlar ile aynı statüde olması için korunmasını emreder. $\mathrm{Bu}$ konuda gerekli hassasiyeti göstermeyen ve kavminin önderlerine tebliğ yapmakla meşgul iken yanlarına gelen bir âmânın zamansız sorularından rahatsız olup yüzünü ekşiten Hz. Peygamber bile Kur'an'da uyarılmıştır (Salebî, 2004: 378; Kurtubî, 2006: 72; Bursevî, 2001: 390; Kutub, 2008: 3822; Ateş, 1989: 320). Kendisine o âmâ geldi diye Peygamber yüzünü ekşitti ve öteye döndü. (Ey Muhammed!) Ne bilirsin, belki de o arınacak. Yahut öğüt alacak da bu ögüt kendisine fayda verecek (Abese, 80/1-3). Bu ayetin nüzulünün ardından Hz. Muhammed, engelliler konusunda daha hassas davranmış, ayette konu olan Abdullah b. Ümmi Mektum'a hürmet babından kürkünü sermiş, Medine dışına çıktığında birden fazla kez onu kendisine vekil tayin etmiştir (İbnu'l-Cevzî, 2010: 399-400; Şirbinî, 2004: 548; İbn Aşur, "tarihsiz": 104; Emiroğlu, 1978: 307-308). En önemlisi Hz. Muhammed, bu ayettin nüzulünden sonra kendi meclisinde dezavantajlı kesimi önemli konuma getirmiştir (Havva, 1990: 34; Sabunî, 2001: 495). Bu da dezavantajlı kesimlerin İslam'da ötekileştirilmediğinin aksine konumlarının daha da güçlendirildiğinin göstergesidir.

\section{Sonuç}

Kur'an; cins, renk ve ırk gibi insanın tercihine bağlı olmayan fitrat niteliklerini üstünlük sebebi olarak görmemekte ve bundan ötürü kimseyi ötekileştirmemektedir. Bununla beraber İslam'da erkek, kadına göre eşitler arası avantajlı bir pozisyona sahiptir (Zuhaylî, 1989: 342).

Farklılıkların farkında olmak, farklılıklara değer verip tanımak ve bunu ortak medeniyet inşasında zenginlik olarak görmek (Gündüz, 2012: 490) İslam'1n önemsediği bir durumdur.

Tebliğ ve teklif noktasında kimseyi öteki kabul etmeyen Kur'an, inanç merkezli bir toplumu esas almakta ve tevhit inancını kabul etmeyen müşrikleri bazı hususlarda öteki 
olarak görmekte ve pislik olarak nitelendirmektedir. Hâkim görüşe göre sırf inanmadı diye müşrik öldürülebilir, kestiğ yenmez ve onunla evlenilmez. Keza Hz. Peygamber'e inanmayan ehlikitap olanlar bir noktada ötekidir. Onunla dostluk yapılmaz ama evlenilebilir. Cizye şartıyla hayatı bağışlanır. Hatta cizye antlaşmayı yapılan kesimler bile yaşamın bazı alanlarında kısıtlanır (Zuhaylî, 1989: 450).

Kur'an, sınıfsal ötekileştirmeyi kabul etmemekte ve engelli, yoksul vb. kesimlerin korunması için bazı ilkeler ortaya koymaktadır.

İnanç merkezli ümmet birliğini esas alan Kur'an, düşmanına dahi adalet vadeden bir tutum ortaya koymakta ve bir arada yaşamın imkânlarını sunmaktadır.

İslam dininin eşitlikçi yaklaşımından ötürü, evvelemirde toplumsal yapı tarafindan ötekileştirilenler tarafindan kabul görmüş, kendilerini üstün görenler tarafından ise reddedilmiştir.

\section{Notlar}

1 Andolsun, biz insanı kuru bir çamurdan, şekillendirilmiş bir balçıtan yarattık. Hicr, 15/28; Hani, Rabbin meleklere şöyle demişti: "Muhakkak ben çamurdan bir insan yaratacağım." Sâd, $38 / 71$.

${ }^{2}$ Hani, Rabbin meleklere, "Ben yeryüzünde bir halife yaratacağım" demişti. Bakara, 2/30.

3 Nefse ve onu düzgün bir biçimde şekillendirip ona kötülük duygusunu ve takvasını (kötülükten sakınma yeteneğini) ilham edene andolsun ki, nefsini arındıran kurtuluşa ermiştir. Şems, 91/78; (Ey Muhammed!) Bizim adımıza de ki, "Ey iman eden kullarım! Rabbinize karşı gelmekten sakının. Zümer, 39/10.

\section{Kaynakça}

Acar, H. İ. (2010). Talâk. D.I..A., XL, 496-500. İstanbul: T.D.V. Yayınları

Akalın, Ş. H., Toparlı, R., Gözaydın, N., Zülfikar, H., Argunşah, M., Demir, N., Tezcan Aksu, B., \& Gültekin, B. (2005). Türkçe Sözlük. Ankara: TDK Yayınları.

Aktan, H. (2008). F1kıh. Íslam'a Giriş-Evrensel Mesaj-. 216229. Ankara: D.İ.B. Yayınları

Aktaş, M. (2014). Avrupa'da Yükselen İslamofobi ve Medeniyetler Çatışması Tezi. Ankara Avrupa Çalışmaları Dergisi, XII-1, 31-54.

Albayrak, İ. (2005). İçimizdeki Öteki: Tefsirde Hâricî (İbâdî) Algılamasına Dair Genel Bir Değerlendirme. Usûl İslam Araştırmaları Dergisi, 4, 1-34.

Alusî, E. (2005). Ruhu'l-Maani fi Tefsiri'l-Kur'ani'l-Azim ve's-Seb'i'l-Mesani. Kahire: Daru'l-Hadis.

Atar, F. (2005). Muhâlea. D.I.A., XXX, 399-402. İstanbul: T.D.V. Yayınları

Ateş, S. (1989). Yüce Kur'an'ın Çăgdaş Tefsiri. İstanbul: Yeni Ufuklar Neşriyat.

Aydın, M. (2009). Dinsel Çoğulculuğun Öteki ile Birlikte Yaşamaya Katkısı Üzerine Bazı Mülahazalar. Milel ve Nihal İnanç, Kültür ve Mitoloji Araştırmaları Dergisi, 6(2), 9-30.
Aydın, M. Â. (2001). Kadın. D.İ.A.,. XXIV, 86-94. İstanbul: T.D.V. Yayınları.

Aydın, M. Â. (2003). Mehir. D.I.A., XXVII, 389-391. İstanbul: T.D.V. Yayınları.

Bardakoğlu, A. (2001). İslâm. D.I.A., XXIII, 15-23. İstanbul: T.D.V. Yayınları.

Bilgin, B. (2001). İslam'da Ötekine Bakıș. Ankara Üniversitesi İlahiyat Fakültesi Dergisi, XLII(1), 11-40.

Bingöl, A. (2015). Kur'an'da Eleştiri Mahiyeti ve Muhataplarl. Doktora Tezi. Van: Yüzüncü Y1l Üniversitesi.

Botî, M. (1996). el-Mer'etu Beyne Tuğyani'n-Nizami'lĞarbiyyi ve Letaifi't-Teşrii'r-Rebbaniyyi. Dimaşk: Daru'l-Fikr.

Buharî, E. (1980). el-Camiu's-Sahih. Kahire: Matbaatu'sSelefiyye.

Bursevî, İ. H. (2001). Ruhu'l-Beyan. Beyrut: Daru'l-İhyai'tTurasi'l-Arabi.

Cevizci, A. (2005). Felsefe Sözlüğü. İstanbul: Paradigma Yayıncilik.

Çalışkan, İ. (2007). Dini Bir Tutum Olarak Ötekine Yaklaşımın Kur'ani Temelleri. C. Ü. Illahiyat Fakültesi Dergisi, 11(1), 7-28.

Çelik, H. A. (1995). Kur'an'1 Kerim'e Göre İnsanın Değeri ve Üstünlüğü. Atatürk Üniversitesi Ilahiyat Fakültesi Dergisi, 12, 81-93.

Dehlan, A. (2001). es-Siretu'n-Nebevîyye. b.y.y.: Daru'lFikr.

Durmuş, Z. (2003). Kur'an-1 Kerim'de Sosyal Gruplar. Dinbilimleri Akademik Araştırma Dergisi, 3(3), 17-46.

Durmuşoğlu, K., \& Kurt, A. (2008). Üç Kur'an Yorumunda Kadının Ötekiliği. Uludağ Üniversitesi İlâhiyat Fakültesi Dergisi, 17(2), 621-648.

Ebu Hayyan, E. (2010). Tefsiru'l-Bahri'l-Muhit. Beyrut: Daru'l-Kutubi'l-İlmiyye.

Ebu Zehra, M. (tarihsiz). Zehretu't-Tefasir. Kahire: Daru'lFikri'l-Arabi.

Ebu's-Suud, M. (2010). Irşadu'l-Akli's-Selim ila Mezaya'lKur'ani'l-Kerim. Beyrut: Muessetu't-Tarihi'l-Arabi.

Elik, H. (2006). el-Kitalu fi "Sebilillah" ve Tedaiyatuhu ke Şiarin İslamiyyin. M. Ü. Illâhiyat Fakültesi Dergisi, 31(2), 119-132.

Elmalı, A. (1999). Kur'ani Çoğulculuk Temelinde Gayri Müslimlerle Dostluk. Harran Üniversitesi Ilahiyat Fakültesi Dergisi, 5, 43-82.

Emiroğlu, H. T. (1978). Esbab-ı Nüzûl. İstanbul: Elif Ofset Tesisleri.

Endulusî, E. (2007). el-Muharreru'l-Veciz fi Tefsiri'lKitabi'l-Aziz. Duha: Daru'l-Fikri'l-Arabi.

Esgin, M. (2014). Kur'ân-1 Kerim'in öteki dinlere karşı tavrı. Bozok Üniversitesi Ilahiyat Fakültesi Dergisi, 5(5), 77106. 
Fayda, M. (2013). Zimmî. D.I.A., XLIV, 428-434. İstanbul: T.D.V. Yayınlar1.

Fentress, J. (2011). Deli “Öteki”, Tarih Eğitimi ve Tarihte "Öteki" Sorunu. 2. Uluslararasl Tarih Kongresi, İstanbul: Tarih Vakfi Yurt Yayınları, 182-200.

Gökkır, B. (2005). Kur'an'daki Ehl-i Kitap “Öteki” mi? İslâm Araştırmalarında Oryantalizmin Kavramsal Etkisi. İslâm Araştırmalarl Dergisi, 14, 37-54.

Gölcük, Ş., \& Toprak, S., (1998). Kelâm. Konya: Tekin Kitabevi.

Gündoğdu, H. (2008). Çok Kültürlü Bir Toplumda Ötekiyle yaşamak ve Hoşgörü. Ekev Akademi Dergisi, 12(37), 7386.

Gündüz, Ş. (2012). Öteki ile İlişkiler Açısından İslam ve İslami Tecrübe. Kutlu Doğum Haftasi "Hz. Peygamber Kardeşlik Ahlakı ve Kardeşlik Hukuku” Sempozyumu, Ankara: D.İ.B. Yayınları, 483-493.

Haddad, E. (2001). Keşfu't-Tenzil fi Tahkiki'l-Mebahisi ve'tTe 'vil. Beyrut: Daru'l-Medari'l-İslam.

Halebî, E. (2008). es-Siretu'l-Halebîyye. Beyrut: Daru'lKutubi'l-İlmiyye.

Hamidullah, M. (2003). İslâm Peygamberi. (çev. Salih Tuğ). Ankara: İmaj.

Havva, S. (1990). el-Esas fi’t-Tefsir. (çev. M. Beşir Eryarsoy). İstanbul: Şamil Yayınevi.

Hökelekli, H. (2007). Müslüman ve Öteki: Farklı Dinî Grupların Birbirini Algılama Biçimi. Kur'ân-ı keim'de Ehl-i Kitap,-Tartışmalı İlmî Toplantı-. İstanbul: 405-420.

İbn Aşur, M. T. (tarihsiz). et-Tahrir ve 't-Tenvir. Tunus: Daru Suhnun.

İbn Hanbel, E. (2001). el-Musned. Beyrut: Muessesetu'rRisale.

İbn Hazm, E. (tarihsiz). el-Muhella. Kahire: Matbaatu'nNehde.

İbn Hişam, E. (2009). es-Siretu'n-Nebevîyye. Beyrut: Daru'l- Marife.

İbn Kudame, E. (1997). el-Muğnî. Riyad: Daru Alemi'lKutub.

İbn Teymîyye, Ş. (tarihsiz). et-Tefsiru'l-Kebir. Beyrut: y.y.

İbnu'l-Cevzî, E. (2010). Zadu'l-Mesir fi İlmi't-Tefsir. Beyrut: Daru'l-Kutubi'l-Arabî.

Karafî, Ş. (1994). ez-Zahîre. Beyrut: Daru'l-Ğarbi'l-İslami.

Kasimî, M. (2003). Mehasinu't-Te’vil. Beyrut: Daru'lKutubi'l-İlmiyye.

Kırbaşoğlu, H. (1997). Kadın Konusunda Kur'ân'a Yöneltilen Başlica Eleştiriler. İslâmî Araştırmalar Dergisi, 10(4), 259-270.

Kurtubî, E. (2006). el-Camiu li Ahkami'l-Kur'an. Beyrut: Muessesetu'r-Risale.

Kutub, S. (2008). Fi Zilali'l-Kur'an. Kahire: Daru'ş-Şuruk.

Maturidî, E. (2005). Te'vilatu'l-Kur'an. İstanbul: Mizan Yayınevi.
Merağ̂̀, A. (1985). Tefsiru Merağ̂̀. Beyrut: Daru'l-İhyai’tTurasi'l-Arabi.

Mevdudî, E. (1997). Tefhimu'l-Kur'an. (çev.: Muhammed Han Kayani vd.). İstanbul: İnsan Yayınevi.

Mezherî, M. (2007). et-Tefsiru'l-Mezherî. Beyrut: Daru'lKutubi'l-İlmiyye.

Müslim, E. (2006). Sahihu Müslim. Riyad: Daru Tayyibe.

Nevevî, E. (1980). Kitabu'l-Mecmu Şerhu'l-Muhezzeb li’şŞirazî. Cidde: Mektebetu'l-İrşad.

Öztürk, M. (2013). Tefsirin Hâlleri. Ankara: Ankara Okulu Yayınları.

Püsküllüoğlu, A. (2010). Arkadaş Türkçe Sözlük. Ankara: Arkadaş Yayınevi.

Razî, E. (2009). et-Tefsiru'l-Kebir. Beyrut: Daru'l-Kutubi'lİlmiyye.

Riza, R., \& Abduh, M. (2005). Tefsiru'l-Menar. Beyrut: Daru'l-Kutubi'l-İlmiyye.

Sabunî, M. (2001). Safvetu't-Tefasir. Beyrut: Daru'l-Fikr.

Sâbûnî, N. (2005). Mâtürîdiyye Akaidi. (çev. Bekir Topaloğlu). Ankara: D.İ.B. Yayınları.

Salebî, E. (2004). el-Keşşaf ve'l-Beyan fi Tefsiri'l-Kur'an. Beyrut: Daru'l-Kutubi'l-İlmiyye.

Salmazzem, M., \& Bingöl, A. (2016). Tefsirlerde Cihada Yönelik Yorum Farklılıkları. Bitlis Eren Üniversitesi Sosyal Bilimler Enstitüsü Dergisi, 5(Ek Say1), 229-246.

Salmazzem, M., \& Sular, M. E. (2014). Tevrat, İnciller ve Kur'an Bağlamında Kadın ve Aile Olgusu. İçinde: Şemsettin Kırış (Ed.), Hakkari Üniversitesi Kadın ve Âile Sorunları Sempozyumu, (s.232-245), Konya.

Sarıçam, İ. (2014). Hz. Muhammed ve Evrensel Mesajl. Konya: D.İ.B. Yayınları.

Serahsî, E. (1989). el-Mebsut. Beyrut: Daru'l-Marife.

Sevinç, B. (2010). Bir Öteki Yaratmak. Toplum Bilimleri Dergisi, 9(7), 177-194.

Siddik Hasan Han, E. (1999). Fethu'l-Beyan fi Makasidi'lKur'an. Beyrut: Daru'l-Kutubi'l-İlmiyye.

Sibaî, M. (2010). el-Mer'etu beyne'l-Fıkhi ve'l-Kanun. Kahire: Daru's-Selam.

Şankitî, M. (2006). Edvau'l-Beyan fi İdahi'l-Kur'ani bi'lKur'an. Beyrut: Daru'l-Kutubi'l-İlmiyye.

Şentürk, R. (2000). İnsan Hakları. D.İ.A., XXII, 327-330. İstanbul: T.D.V. Yayınları.

Şimşek, S. (2012). Hayat Kaynă̆ı Kur'an Tefsiri. İstanbul: Beyan Yayınları.

Şirbinî, Ş. (2004). es-Siracu'l-Munir fi'l-İaneti ala Marifeti Ba'di Maani Kelami Rebbina'l-Hekimi'l-Habir. Beyrut: Daru'l-Kutubi'l-İlmiyye.

Taberî, E. (t.y.). Camiu'l-Beyan an Te'vili'l-Kur'an. Beyrut: Daru'l-İhyai't-Turasi'l-Arabi.

Taftazanî, M. (t.y.). Şerhu Akaid. b.y.y. 
Tekeli, İ. (2011). Tarihyazıcıllı̆ı Ve Öteki Kavramı Üzerinde Düşünceler. Tarih Eğitimi ve Tarihte "Öteki" Sorunu, 2. Uluslararası Tarih Kongresi, İstanbul: Tarih Vakfı Yurt Yayınlar1, 1-12.

Tirmizi, E. (1978). el-Camiu's-Sahih. Misır: Matbaatu'lMustafa el-Babî.

Toprak, B., Bozan, İ., Morgül, T., \& Şener, N. (2010). Türkiye'de Farkl Olmak Din Ve Muhafazakarlik Ekseninde Ötekileştirilenler. İstanbul: Metis Yayıncılık.

Türk, D. (2013). Öteki, Düssman, Olay Levinas, Schmitt ve Badıou'da Etik ve Siyaset. İstanbul: Metis Yayıncılık.

Yadsıman, N. (2003). Kur'an-Sünnet-Fikıh Bağlamında Kadının Evlilikteki Hakları. İzmir: Kanyılmaz Matbaası.

Yaman, A. (2008). Ben ve "Öteki” Kur'an'ın "Öteki” ile İlişkilerde Öngördüğü Dengeli Barış Teorisi. İslami İlimler Dergisi, 3(1), 99-106.

Yaman, A. (2013). Zimmî. D.İ.A., XLIV, 434-438. İstanbul: T.D.V. Yayınları.

Yıldırım, T. (2012). Cizre'de Değişen Öteki Algısı, Çokkültürlülük ve Birarada Yaşamanın Temelleri. İçinde: M. Nesim Doru (Ed.), Bilim Düşünce ve Sanatta Cizre, (Uluslararası Bilim Düsünce ve Sanatta Cizre Seтроzуити Bildirileri,, (s.169-174), İstanbul.

Yılmaz, Ö. (2008). Öteki İle Diyalojik İlişkinin Gereği. Avrupa İslam Üniversitesi İslam Araştırmaları, 1(1), 137-145.

Yurdaydın, H. G. (1986). İslâm Devletinde Müslüman Olmayanların Durumu. Ankara Üniversitesi Ilahiyat Fakültesi Dergisi, 27(1), 97-110.

Zemahşerî, M. (2009). el-Keşşaf an Hakaiki Ğavamidi'tTenzil ve Uyunui'l-Akavili fi Vucuhi't-Te'vil. Beyrut: Daru'l-Kutubi'l-İlmiyye.

Zeydan, A. (1994). İslam Hukukuna Göre Zimmiler. (çev. Hasan Güleç). D.E.Ü. Ilâhiyat Fakültesi Dergisi, 8, 431440.

Zuhaylî, V. (1989). el-Fikhu'l-İslamiyyu ve Edilletuhu. Dimaşk: Daru'l-Fikr. 